\title{
Separation of Biosynthetic Products by Pertraction
}

\author{
Anca-Irina Galaction ${ }^{1}$ and Dan Caşcaval ${ }^{2}$ \\ 1"Grigore T. Popa" University of Medicine and Pharmacy of Iasi, \\ Faculty of Medical Bioengineering, Dept. of Biotechnologies \\ 2"Gheorghe Asachi" Technical University of Iasi, \\ Faculty of Chemical Engineering and Environmental \\ Protection, Dept. of Biochemical Engineering
}

Romania

\section{Introduction}

The industrial biotechnology has been considerably developed in the last years, especially for the fine chemicals production and food technologies (Caşcaval \& Galaction, 2007). This evolution of the biotechnology at large-scale is supported by favorable political and social sentiments and leads to the gradually replace of the chemical technologies by sustainable biochemical technologies with significant benefits.

According to the Lisbon strategy, the improvement of the current technologies was the major objective until 2010 and remains an economic, technological and social challenge (Daugherty, 2006). This objective can be reached by defining an unitary vision concerning the world industrial biotechnology, by ensuring feasible framework programs for developing biotechnology, by increasing through knowledge and transparent information the public interest and support on industrial biotechnology, by establishing the partnerships between the public and private institutions. Thus, the new concept of "white biotechnology" is considered to be the "New Era" of biotechnology and joins all the initiatives dedicated to producing goods or services by sustainable biotechnologies. Being directed to the identification and utilization of the natural renewable sources of raw materials for biosynthesizing valuable bioactive compounds, by means of clean processes which will cut the waste generation and high energy consumption, the driving force of the white biotechnology is the sustainability by carefully managing of the finite resources. Therefore, according to the definition given by Gro Harlem Brundtland, the former Chair of the World Commission on Environment and Development, in its report Our common future (April 1987), the sustainable development imposes the equilibrium of three equally important requirements, of economic, ecologic and social types. This idea has been also underlined by Thomas Rachel, German Presidency of the Council of the European Union at the opening ceremony of the International Conference European BioPerspectives - "En Route to a Knowledge-Based Bio-Economy"(31 May - 1 June 2007, Cologne) (Caşcaval \& Galaction, 2007). It is very important to think about the "white biotechnology" not only in terms of its potential economic benefits, but also in terms of environmental protection or of the starting- 
point for new business. The industrial biotechnology has became a hot topic especially among the manufacturers and companies using chemical synthesis technologies, because the biotechnology possesses the potential to improve and, then, to maintain the level of products competitiveness.

In this context, the actual trend to implement the "white biotechnology", defined as "the third wave of the biotechnology" too, is also dedicated to the design, optimization and application at macro-scale of new techniques for separation and purification. Compared to the chemical methods, the biosynthesis represents a very advantageous alternative for production of many compounds with biological activity, because of the reduction of the overall process stages number and of the advanced utilization of the low-cost raw materials. However, the undesirable particularity of industrial biotechnologies is the complexity of the separation from fermentation broths of the obtained products, especially due to their high dilution in broth, chemical and thermal lability and to the presence of secondary products. Therefore, the purification of biosynthetic compounds requires a laborious succession of separation stages with high material and energy consumption, the contribution of these stages to the overall cost being of 20 - 60\%, or even more (Baird, 1991; Schugerl, 1994).

For these reasons, modern techniques have been developed or adapted for the separation of the biosynthetic products. Derived from the "classical" solvent extraction method, some new extraction techniques, namely as: reactive extraction, extraction and transport through liquid membranes, supercritical fluid extraction, two aqueous phases extraction, extraction by reverse micelles, have been experimented and applied at laboratory or industrial scale for bioseparations. One of the most attractive techniques is pertraction, defined as the extraction and transport through liquid membranes. Pertraction consists in the transfer of a solute between two aqueous phases of different $\mathrm{pH}$ or other chemical properties value, phases that are separated by a solvent layer of various sizes (Noble \& Stern, 1995; Yordanov \& Boyadzhiev, 2004; Kislik, 2010). The pertraction efficiency and selectivity could be significantly enhanced by adding a carrier, such as organophosphoric compounds, long chain amines or crown-ethers etc., into the liquid membrane, the separation process being called facilitated pertraction or facilitated transport (Li, 1978; Teramoto et al., 1990; Juang et al., 1998; Scovazzo et al., 2002; Luangrujiwong et al., 2007; Caşcaval et al., 2009).

The liquid membranes can be obtained either by emulsification, but their stability is poor, by including the solvent in a hydrophobic porous polymer matrix, or by using pertraction equipments of special construction, which allow to separate and easily maintain the three phases without adding surfactants (free liquid membranes) (Caşcaval et al., 2009).

Compared to the physical or reactive liquid-liquid extraction, the use of pertraction reduces the loss of solvent during the separation cycle, needs small quantity of solvent and carrier, owing to their continuous regeneration, and allows the solute transport against its concentration gradient, as long as the $\mathrm{pH}$-gradient between the two aqueous phases is maintained (Baird, 1991; Schugerl, 1994; Fortunato et al., 2004; Kislik, 2010).

Beside the separation conditions and the physical properties of the liquid membrane, the pertraction mechanism and, implicitly, its performance are controlled by the solute and carrier characteristics, respectively by their ability to form products soluble in the liquid membrane. Among the mentioned factors, the $\mathrm{pH}$-difference between the feed and stripping phase exhibits the most significant influence, this parameter controlling the yields and selectivities of the extraction and reextraction processes, on the one hand, and the rate of the solute transfer through the solvent layer, on the other hand.

Because of its generous offer in the field of biosynthetic compounds separation, pertraction represents a continuous challenge for bioengineering and biotechnology. Thus, this Chapter 
presents the main results of our experiments on individual or selective separation of some biosynthetic products (antibiotics, carboxylic acids, amino acids, vitamins) by free or facilitated pertraction, using carriers of long chain amines or organophosphoric acids types.

\section{Selective pertraction of Penicillin V}

The biosynthesis of beta-lactamic antibiotics (Penicillins G and V) by Penicillium $s p$. or Aspergillus sp. requires the use of precursors (phenylacetic acid, or phenoxyacetic acid, respectively). Due to their toxicity, the precursors are added in portions during the fermentation, their concentration being maintained at a constant level. Therefore, the acids final concentrations in the fermentation broth vary between 0.2 and $0.6 \mathrm{~g} / 1$, depending on the strain and biosynthesis conditions. For this reason, the selective separation is required for obtaining beta-lactamic antibiotics with high purity. Although this operation is difficult by using conventional separation techniques due to the similar physical and chemical characteristics, the antibiotics can be selectively separated from their precursors by facilitated pertraction with Amberlite LA-2 in 1,2-dichloroethane (Caşcaval et al., 2000).

For Penicillin $\mathrm{V}$, the experiments emphasized the major role of $\mathrm{pH}$ on the permeability through liquid membrane and selectivity of separation of this antibiotic from phenoxyacetic acid. Thus, the permeability factor, $\mathrm{P}$, is positively influenced by increasing the $\mathrm{pH}$-gradient between the two aqueous phases (the permeability factor conveys the capacity of a solute transfer through liquid membrane, and has been defined as the ratio between the final mass flow and the initial mass flow of solute).

Contrary, Figure 1 indicates that the maximum values of selectivity factor, $\mathrm{S}$, correspond to the minimum difference between the $\mathrm{pH}$-values of the aqueous phases (the selectivity factor has been defined as the ratio between the final mass flow of antibiotic and the final mass flow of precursor). Thus, at a constant level of stripping phase $\mathrm{pH}$ of 10 and for a $\mathrm{pH}$-value for feed phase of $6, \mathrm{~S}$ was 80.4 . If the $\mathrm{pH}$-value of feed phase is maintained at 3 and the $\mathrm{pH}$ value of stripping phase is of 7 , the value $S=24.2$ was obtained.
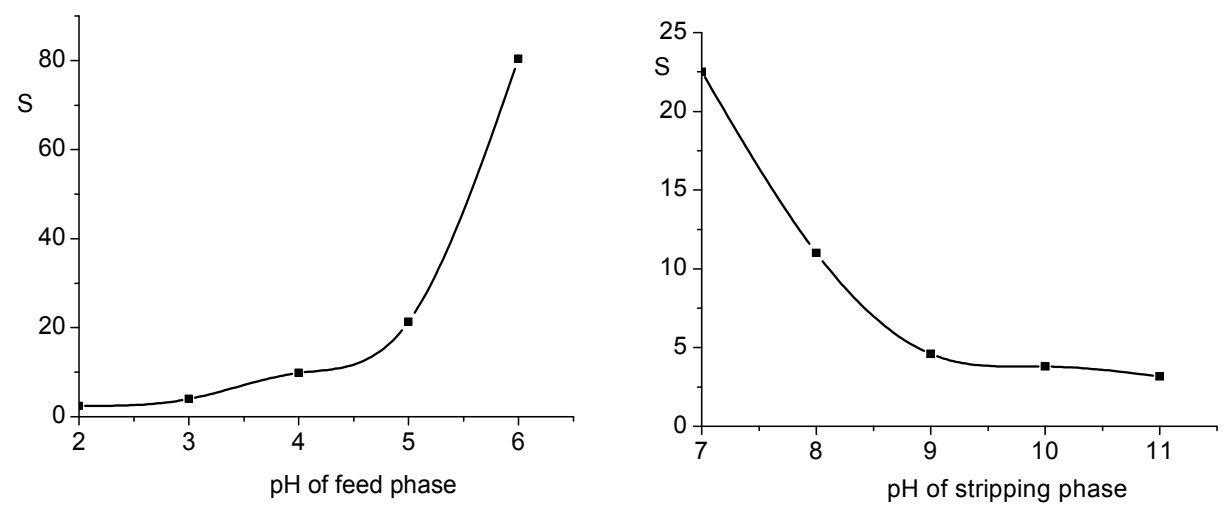

Fig. 1. Effect of feed phase and stripping phase $\mathrm{pH}$-values on the selectivity factor (rotation speed $=500 \mathrm{rpm}$, carrier concentration $=80 \mathrm{~g} / \mathrm{l}$ ) 
Another important factor is the concentration of Amberlite LA-2 inside the liquid membrane. Although the effect of this factor is quite similar for the two components of mixture, at lower carrier concentration the decrease of permeability factor of phenoxyacetic acid is more significant. By increasing the Amberlite LA-2 concentration inside the liquid membrane, the approaching of the permeability factors of the two compounds can be observed. This phenomenon, indicated in Figure 2 by the ratio of permeability factors, suggests that at low carrier concentrations it preferentially reacts with the compound of higher acidity, namely Penicillin V.

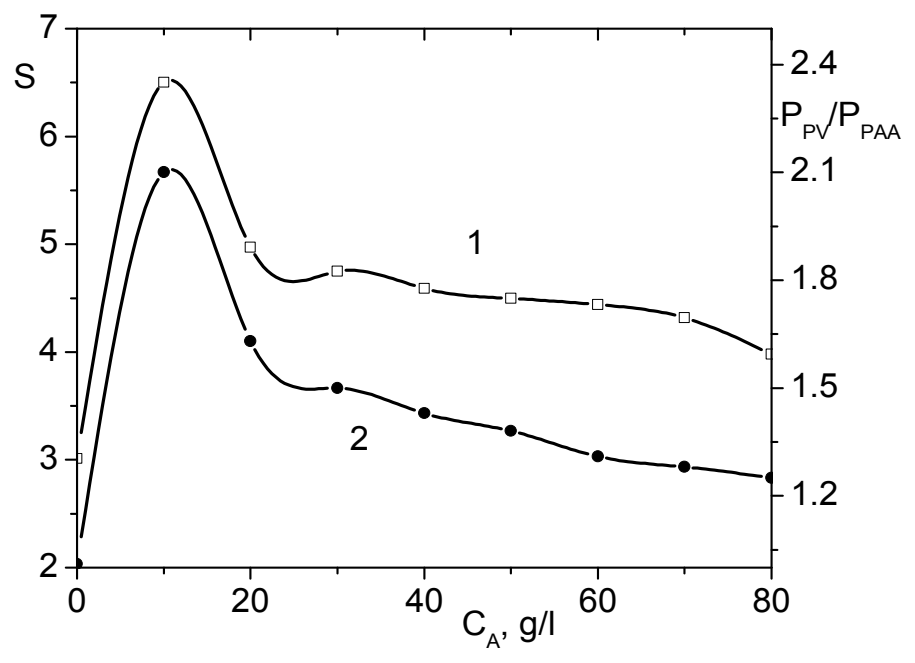

Fig. 2. Effect of carrier concentration on the ratio between permeability factors of Penicillin $\mathrm{V}$ and phenoxyacetic acid and on the selectivity factor $(\mathrm{pH}$-value of feed phase $=3, \mathrm{pH}$-value of stripping phase $=10$, rotation speed $=500 \mathrm{rpm}$; 1 - selectivity factor $\left.\mathrm{S}, 2-\mathrm{P}_{\mathrm{PV}} / \mathrm{P}_{\mathrm{PAA}}\right)$

At high Amberlite LA-2 concentrations, additional amounts of carrier will be available nearly the interface, means that the carrier will react also with the weaker acid, namely phenoxyacetic acid. These results have been found in the variation of selectivity factor, which reached the maximum value of 6.5 for $10 \mathrm{~g} / 1$ Amberlite LA-2 inside the liquid membrane.

\section{Direct pertraction of Erythromycin}

Erythromycin is a macrolide antibiotic biosynthesized by Streptomyces erythreus on glucose substrate, being very active against the infections produced by staphylococcus, gram-positive bacterium, etc. Erythromycin exhibits a significant inhibitory effect, this leading to the diminution of microbial activity or cells lysis with the antibiotic accumulation in the broth (Galaction \& Caşcaval, 2006). The phenomenon can be avoided by direct removal of antibiotic during the fermentation process.

At industrial scale, the antibiotic separation from fermentation broths is carried out by physical extraction with butyl acetate, with or without preliminary filtration of biomass, followed by its reextraction with diluted solutions of hydrochloric acid. Due to 
Erythromycin dissociation and to the low polarity of butyl acetate, the physical extraction is possible only in alkaline $\mathrm{pH}$-domain, the maximum extraction yields being reached for the $\mathrm{pH}$-value of aqueous phase greater than 9 (Galaction \& Caşcaval, 2006). In these conditions, some other components of fermentation broths, which are non-dissociated at the extraction $\mathrm{pH}$-value, can be supplementary extracted, the ulterior purification of the antibiotic becoming more difficult.

For the above mentioned reason, a new separation method of Erythromycin from aqueous solutions by reactive extraction with di-(2-ethylhexyl) phosphoric acid (D2EHPA) has been investigated (Caşcaval \& Galaction, 2004). This method has been developed and applied as facilitated pertraction, the addition of D2EHPA inside the liquid membrane allowing to increasing the antibiotic mass flow compared to the free pertraction without any carrier (Kawasaki et al., 1996; Caşcaval et al. 2007). But, in the case of media possessing rheological behavior and apparent viscosity similar to the S. erythreus broths, the efficiency of pertraction was strongly affected. The increase of apparent viscosity of feed phase from 1 to $30 \mathrm{cP}$ led to the maximum decrease of antibiotic mass flows by the factors of 42.5 and 7.5 for free and facilitated pertraction, respectively (Galaction et al., 2009).

Similar to the direct extraction of other biosynthetic compounds from the fermentation broths (Katikaneni \& Cheryan, 2002; Monteiro et al., 2005; Vijayakumar et al., 2008; Kang \& Sim, 2008), the presence of biomass could supplementary affect the Erythromycin pertraction, owing to the following phenomena: the appearance of supplementary resistance to the antibiotic transfer from the feed phase to the liquid membrane due to the physical barrier induced by the cell adsorption to the interface; the increase of the apparent viscosity of the feed phase, and, consequently, the amplification of antibiotic diffusional resistance; the mechanical lysis of cells, as the result of the shear stress promoted by the impellers, with the release of the cytoplasmatic compounds which can be co-extracted (amino acids) or can precipitate (proteins).

The study on Erythromycin pertraction from aqueous solutions or simulated broths indicated that the free pertraction is not possible for the $\mathrm{pH}$-value of feed phase, $\mathrm{pH}_{\mathrm{f}}$, lower than 4, due to the pronounced antibiotic ionization (Caşcaval et al. 2007; Galaction et al., 2009). By increasing the $\mathrm{pH}_{\mathrm{f}}$ above this level, both the initial and final mass flows are strongly increased, as the result of the increase of physical extraction efficiency. This dependence between the mass flows and the $\mathrm{pH}$ of feed phase is respected also in the case of Erythromycin free pertraction from S. erythreus suspensions (Figure 3).

But, the accumulation of biomass led to the significant decrease of the initial mass flow (by increasing the biomass concentration from 0 to $20 \mathrm{~g} / 1 \mathrm{~d} . \mathrm{w}$. , the initial mass flow has been reduced for about 7 times).

The increase of the stripping phase $\mathrm{pH}$-value, $\mathrm{pH}_{\mathrm{s}}$, leads to the significant reduction of the antibiotic initial mass flow, this effect becoming more pronounced with the microorganism accumulation in the feed phase. In this case, the negative influence of the biomass is amplified by increasing $\mathrm{pH}_{\mathrm{s}}$, as the result of the supplementary effect of the neutral domain of $\mathrm{pH}_{\mathrm{s}}$ (by increasing the biomass concentration from 0 to $20 \mathrm{~g} / \mathrm{l}$ d.w., the initial mass flow of Erythromycin decreasing for about 5.8 and 19.2 times at $\mathrm{pH}_{\mathrm{s}}$ of 2 and 7, respectively). The decreasing of the final mass flow is more important, this parameter reaching the value 0 for $\mathrm{pH}_{\mathrm{s}}$ over 7 (at this value of $\mathrm{pH}_{\mathrm{s}}$ the $\mathrm{pH}$-gradient between the feed and stripping phases becomes 0 ). The increase of $S$. erythreus concentration induces the supplementary decrease of antibiotic final mass flow. Thus, comparatively with the pertraction from water, at $20 \mathrm{~g} / 1$ 
d.w. S. erythreus the final mass flow of Erythromycin is reduced for about 2.8-5.8 times, this effect being amplified at lower values of $\mathrm{pH}_{\mathrm{s}}$.
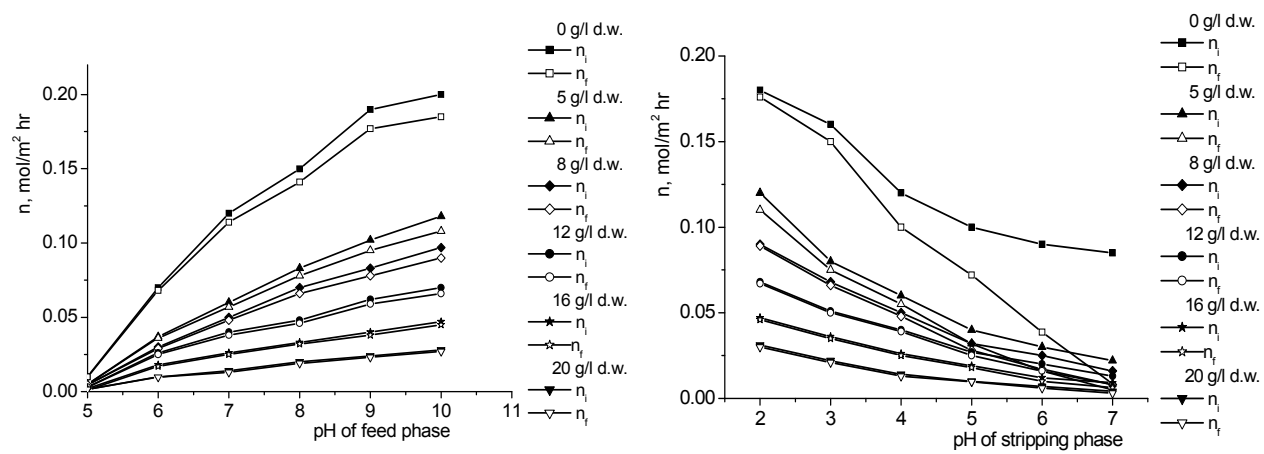

Fig. 3. Influence of $\mathrm{pH}$-values of feed and stripping phases on initial, $\mathrm{n}_{\mathrm{i}}$, and final, $\mathrm{n}_{\mathrm{f}}$, mass flows of Erythromycin for free pertraction from S. erythreus broths (rotation speed $=500$ rpm)

Independently on the biomass concentration in the feed phase, the permeability factor is continuously reduced by the increase of $\mathrm{pH}_{\mathrm{f}}$ over 4 , this suggesting that $\mathrm{pH}_{\mathrm{f}}$ exhibits a more important influence on the initial mass flow than on the final one (Figure 4).
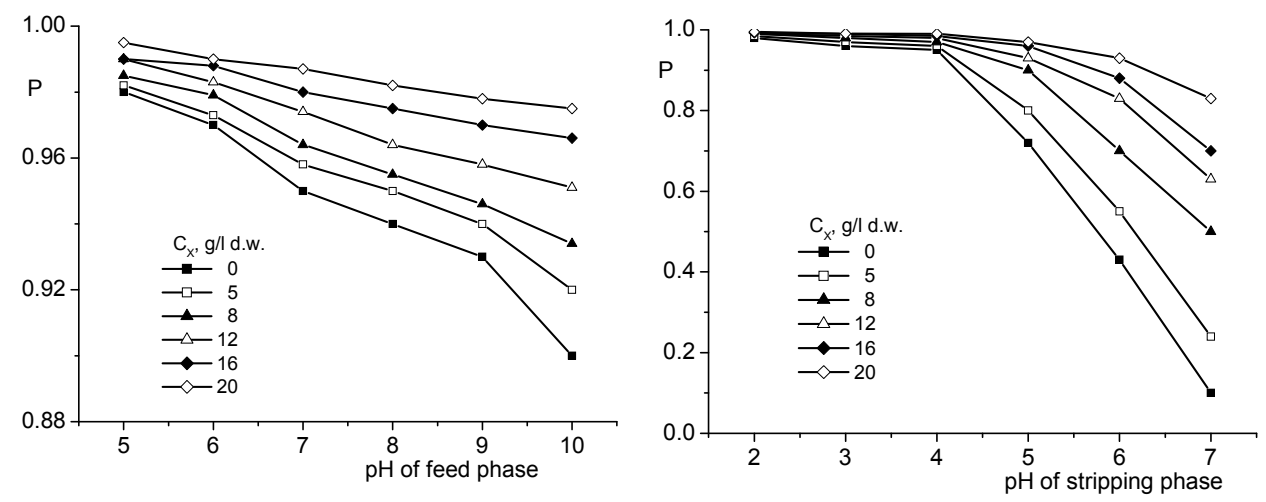

Fig. 4. Influence of $\mathrm{pH}$-values of feed and stripping phases on permeability factor for free pertraction from S. erythreus broths (rotation speed $=500 \mathrm{rpm}$ )

The magnitude of the effect of $\mathrm{pH}_{\mathrm{f}}$ is diminished with the biomass accumulation, because the amount of antibiotic extracted in the liquid membrane becomes lower, thus facilitating its almost complete reextraction in the stripping phase.

For quantifying the effect of biomass presence, the reduction factor, $\mathrm{F}$, has been defined as the ratio between the initial mass flows corresponding to the pertraction from S. erythreus broths and simulated ones (without biomass), $\mathrm{F}_{\mathrm{i}}$, respectively between the final mass flows recorded for the same two cases, $\mathrm{F}_{\mathrm{f}}$. The influence of the biomass is clearly underlined in the Figure 5, being recorded the reduction of over 3 times of the factors $F_{i}$ and $F_{f}$ with the accumulation of biomass to $20 \mathrm{~g} / 1 \mathrm{~d} . \mathrm{w}$. This effect is stronger for $S$. erythreus concentration 
increase up to $5 \mathrm{~g} / \mathrm{l}$ d.w., thus emphasizing the important role of solid phase in hindering the pertraction.

The addition of the carrier, di-(2-ethylhexyl) phosphoric acid, D2EHPA, in the liquid membrane offers the possibility to carry out the pertraction also at $\mathrm{pH}$-values lower than 4 , due to the modification of the mechanism of Erythromycin extraction in the dichloromethane phase. Thus, the previously proposed and verified mechanism of antibiotic reactive extraction with D2EHPA occurs by means of an interfacial reaction of ionic exchange type controlled by the $\mathrm{pH}$ of aqueous phase (Caşcaval \& Galaction, 2004):

$$
\mathrm{Er}-\mathrm{N}^{+} \mathrm{H}\left(\mathrm{CH}_{3}\right)_{2(\mathrm{aq})}+\mathrm{HP}_{(\mathrm{o})} \rightleftarrows \mathrm{Er}-\mathrm{N}^{+} \mathrm{H}\left(\mathrm{CH}_{3}\right)_{2} \mathrm{P}_{(\text {(o) }}^{-}+\mathrm{H}_{(\text {(aq) }}^{+}
$$

where HP is the carrier. According to the extraction mechanism, the carrier reacts only if Erythromycin exists in aqueous solution in its cationic forms, therefore at an acidic $\mathrm{pH}$-value of the solution $\left(\mathrm{pH}_{\mathrm{f}}<4\right)$.

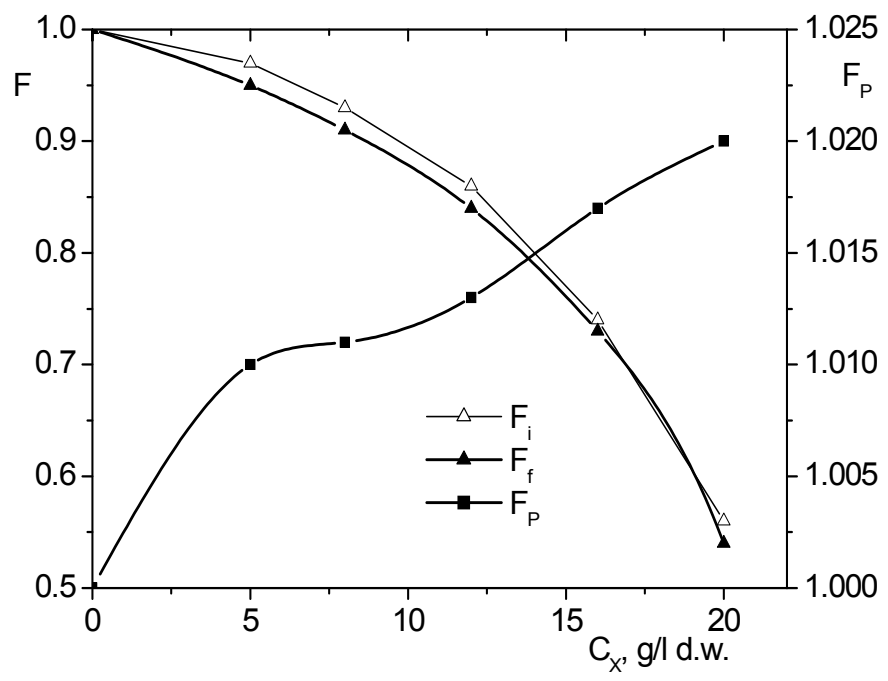

Fig. 5. Influence of biomass concentration, $C_{X}$, on factors $F$ and $F_{P}$ for facilitated pertraction from $S$. erythreus broths ( $\mathrm{pH}$ of feed phase $=4$, $\mathrm{pH}$ of stripping phase $=2$, carrier concentration $=40 \mathrm{~g} / \mathrm{l}$, rotation speed $=500 \mathrm{rpm}$ )

In the case of facilitated pertraction, the accumulation of biomass from 0 to $20 \mathrm{~g} / 1 \mathrm{~d} . \mathrm{w}$. led to the reduction for about 1.8 times of the factors $F_{i}$ and $F_{f}$. Comparatively to the free pertraction, the magnitude of this effect is attenuated by D2EHPA addition, which increases the initial mass flows of Erythromycin. The dependence between the factor $F_{P}$ and biomass concentration is opposite to those describing the variation of mass flows ratios. According to those concluded for the free pertraction, the accumulation of $S$. erythreus induces the equalization of the final and initial mass flows. For this reason, the permeability factors are greater for the facilitated pertraction from $S$. erythreus broths than those for the facilitated pertraction from simulated broths, thus leading to the increase of the factor $F_{P}$ with the biomass concentration. 


\section{Selective pertraction of Gentamicins}

Gentamicin is an aminoglycoside antibiotic, isolated in 1963 by Weinstein from the Micromonospora purpurea cultures. It was introduced in therapeutic practice in 1969 in USA. Gentamicin has a broad spectrum against the aerobic Gram positive and Gram negative bacteria, including the strains resistant to tetracycline, chloramphenicol, kanamycin, and colistin, namely Pseudomonas, Proteus, Staphylococcus, Streptococcus, Klebsiella, Haemophilus, Aerobacter, Moraxella and Neisseria. It was the first antibiotic efficient against Pseudomonas, being one of the most important members of the aminoglycoside antibiotics family (Korzybski, 1978; Williams \& Lemke, 2002). This antibiotic is industrially obtained by Micromonospora purpurea or echinospora biosynthesis, the product being a complex mixture of some components of very similar structures. Among them, three are the most important: Gentamicins $C_{1}, C_{1 a}$ and $C_{2}$ (Gentamicin $C_{2 a}$ is considered also to be Gentamicin $C_{2}$, because it is its stereoisomer) (Isoherranen \& Soback, 2000; Silverman, 2004). The biosynthetic complex contains also the active Gentamicin $\mathrm{C}_{2 \mathrm{~b}}$, but its concentration is very low. The chemical structures of the major Gentamicins are indicated in Figure 6.

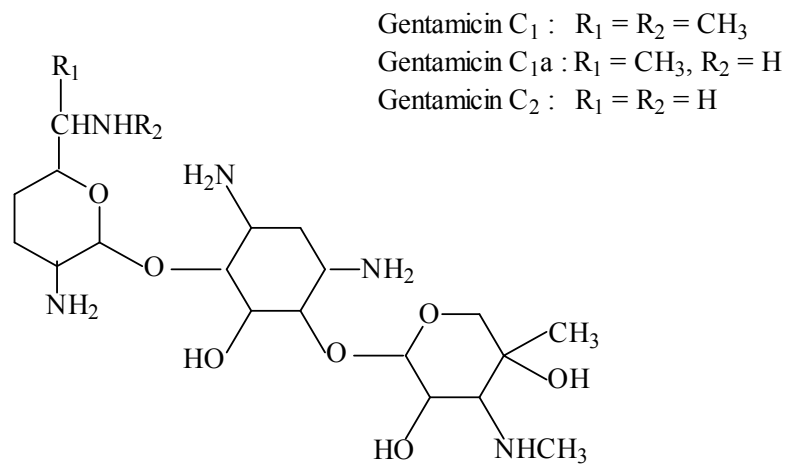

Fig. 6. Chemical structure of biosynthetic Gentamicins

The ratio of these components in the mixture varies from one biosynthetic product to another, the average values of their concentrations being: Gentamicin $C_{1} 35 \%$, Gentamicin $\mathrm{C}_{1 \mathrm{a}} 25 \%$, Gentamicin $\mathrm{C}_{2}$ (including Gentamicin $\mathrm{C}_{2 \mathrm{a}}$ ) 40\% (Yoshizawa et al., 1998). The antibacterial activities of the Gentamicins, respectively their affinities for the bacterial ribosomes, are different. Thus, the most efficient is Gentamicin $C_{1 a}$, its activity being slightly higher than that of Gentamicin $C_{2}$. Gentamicin $C_{1}$ binds the ribosomal subunits with the lowest efficiency compared with the other two Gentamicins (there are no reports concerning the specific affinity of Gentamicin $\mathrm{C}_{2 a}$, probably due to its assimilation with Gentamicin $\mathrm{C}_{2}$ ) (Rosenkrantz et al., 1980).

The separation of Gentamicin from the fermentation broths at industrial scale is achieved by sorption by cation-exchangers, followed by its desorption with a solution of $4-5 \%$ sulfuric acid. After the neutralization, the solution is purified and concentrated under vacuum, the antibiotic being precipitated as sulfate salt by acetone addition (Savitskaya et al., 1982). But, this technique doesn't allow the fractionation of the complex mixture of Gentamicins, the use only of Gentamicins $C_{1 a}$ and $C_{2}$ improving the specific biological activity per weight unit of antibiotic. 


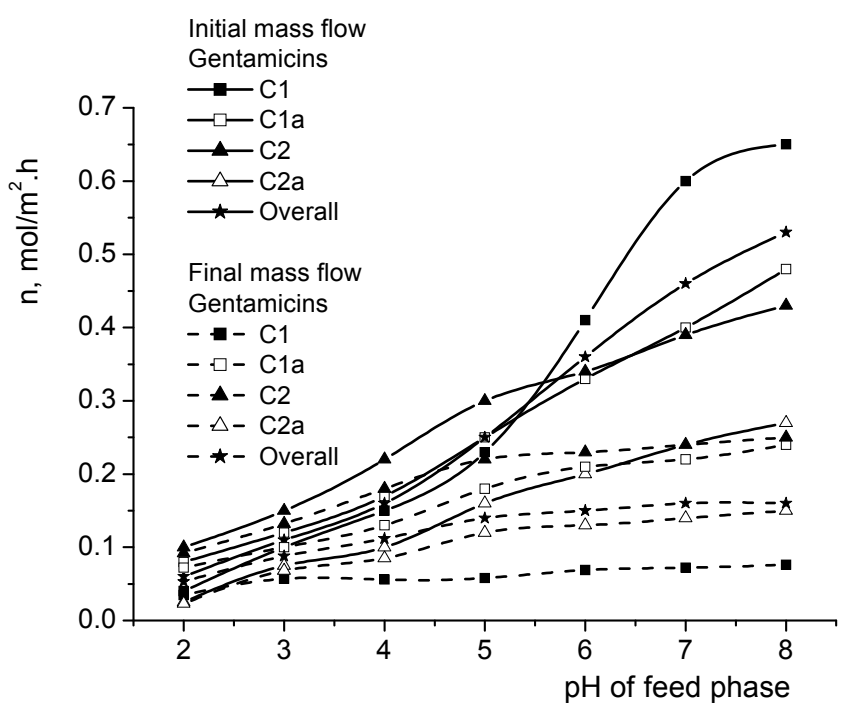

Fig. 7. Influence of $\mathrm{pH}$-value of feed phase on mass flows of Gentamicins ( $\mathrm{pH}$ of stripping phase $=1.5$, D2EHPA concentration $=20 \mathrm{~g} / \mathrm{l}$, rotation speed $=500 \mathrm{rpm}$ )

The investigations on the reactive extraction of Gentamicins (Caşcaval et al., 2007) have been developed by studying the possibility to fractionate the biosynthetic mixture of Gentamicins by facilitated pertraction with D2EHPA dissolved in dichloromethane as liquid membrane (Galaction et., 2008). The influence of $\mathrm{pH}$-gradient on the Gentamicins pertraction is amplified by the ionization-protonation of these antibiotics in the two aqueous phases, these processes controlling the efficiency of extraction and re-extraction, as well as the rate of the transport through liquid membrane. Thus, from Figure 7 it can be observed that the initial and final mass flows of Gentamicins are continuously increased with the increase of $\mathrm{pH}-$ value. This variation is the result of the mechanism of reactive extraction of the Gentamicins. According to the previous studies, the reactive extraction with D2EHPA occurs by means of the formation of a strong hydrophobic compound by the following ionic exchange reaction (Caşcaval et al., 2007):

$$
\text { Gentamicin }_{(\mathrm{aq})}^{\mathrm{n+}}+\mathrm{nHP}_{(\mathrm{o})} \rightleftarrows \text { Gentamicin.nHP } \mathrm{oo}_{(\mathrm{o})}+\mathrm{n} \mathrm{H}_{(\mathrm{aq})}^{+}
$$

where Gentamicin ${ }^{\mathrm{n}+}$ represents the antibiotic with protonated aminic groups, and HP the carrier, respectively $(n=1-5)$. The aminic groups of Gentamicins are involved in the reactive extraction, the interactions between the antibiotic and extractant being of ionic type. Gentamicins possess five aminic groups, which could react with the extractant, similar to the reaction with sulfuric acid in the desorption process from the cation-exchangers (Savitskaya et al., 1982). But, due to the voluminous molecules of the antibiotic and extractant, the steric hindrances appear, thus limiting the number of the aminic groups that can react. Furthermore, the basic character of the aminic groups is different and induces the competition between them in the reaction with D2EHPA. The substitutes, which differentiate the Gentamicins, control the basicity of the specific aminic groups and induce their different reactivity, respectively their different mass flows. 
Although the effect of the $\mathrm{pH}$-value of feed phase is similar for all Gentamicins, for the neutral $\mathrm{pH}$ domain there were recorded important modifications of the relative extraction rate of the four Gentamicins in the membrane phase. For $\mathrm{pH}$-value below 5 the order of the increase of initial mass flows is due to the decrease of dissociation degree from Gentamicin $\mathrm{C}_{1}$ to Gentamicin $\mathrm{C}_{2}$, being as follows:

$$
\text { gentamicin } C_{2}>\text { gentamicin } C_{1 a}>\text { gentamicin } C_{1}>\text { gentamicin } C_{2 a} \text {. }
$$

This order also indicated significant difference between the initial mass flows of the Gentamicins $\mathrm{C}_{2}$ and $\mathrm{C}_{2 \mathrm{a}}$, both compounds having the same chemical structure and molecular weight. This phenomenon could be the result of the molecular conformation of Gentamicin $C_{2 a}$, which alters the strength of the interactions of solvation type with the solvent molecules, and, consequently, its solubility in dichloromethane. For $\mathrm{pH}$-values of feed phase over 5 , the initial mass flows of Gentamicins $C_{1}$ and $C_{1 a}$ become superior to those of the other two Gentamicins. The reactive extraction with D2EHPA needs the protonation of Gentamicins in aqueous solution, this process being affected by the $\mathrm{pH}$ increase. Due to the different basicity of Gentamicins specific substituted aminic groups, the relative magnitude of the $\mathrm{pH}$ influence on initial mass flows is different. Thus, the increase of the mass flow for $\mathrm{pH}$-value over 5 becomes more pronounced for the Gentamicin containing aminic groups with higher basicity, namely Gentamicin $C_{1}$. For the reasons above considered, the lowest mass flow was recorded for Gentamicin $\mathrm{C}_{2 \mathrm{a}}$.

For describing the selectivity of pertraction, the selectivity factor, $S$, has been used, being defined as the ratio between the permeability factor of all Gentamicins and that of Gentamicin $C_{1}$. According to the above results, from Figure 8 it can be seen that the variation of $\mathrm{pH}$ of feed phase from 2 to 8 exhibits a favorable influence of the selectivity factor, this parameter increasing from 1 to 3.1 in the considered domain of $\mathrm{pH}$.

The increase of stripping phase $\mathrm{pH}$-value induces the significant reduction of initial and final mass flows of all Gentamicins (Figure 9). This variation is controlled by the reextraction mechanism, which is based on the interfacial reaction between the GentamicinsD2EHPA salts and five equivalents of sulfuric acid for each mole of Gentamicin (Savitskaya et al., 1982; Caşcaval et al., 2007):

$$
\text { Gentamicin. } \mathrm{HP}_{(\mathrm{o})}+5 / 2 \mathrm{H}_{2} \mathrm{SO}_{4(\mathrm{aq})} \rightleftarrows \text { Gentamicin }^{5+} .5 / 2 \mathrm{SO}_{4}^{2-}{ }_{(\mathrm{aq})}+\mathrm{HP}_{(\mathrm{o})}
$$

The reactivity of Gentamicins in the reaction with sulfuric acid is determined also by the basicity of their specific aminic groups, because they control the strength of the ionic interactions between the antibiotic and the carrier, and therefore the easiness of the antibiotic release from the membrane phase. Figure 9 indicates that at higher acidic $\mathrm{pH}$ domain of stripping phase the highest initial mass flow corresponds to Gentamicin $\mathrm{C}_{1}$. The decrease of the sulfuric acid concentration, respectively the increase of stripping phase $\mathrm{pH}$ value, leads to the decrease of all Gentamicins initial mass flows, this variation being more pronounced for Gentamicin $\mathrm{C}_{1}$. Therefore, for $\mathrm{pH}$-value over 2 the initial mass flow of Gentamicin $C_{1}$ becomes lower than those of the other Gentamicins. This evolution is due to the different basicity of the specific aminic groups of Gentamicins, which induces different rates of re-extraction in the stripping phase, consequently different concentration gradients of Gentamicins between the two aqueous phases. At lower $\mathrm{pH}$-value, the concentration gradients are maximum and, therefore, the extracted mass flows of all Gentamicins are high. 


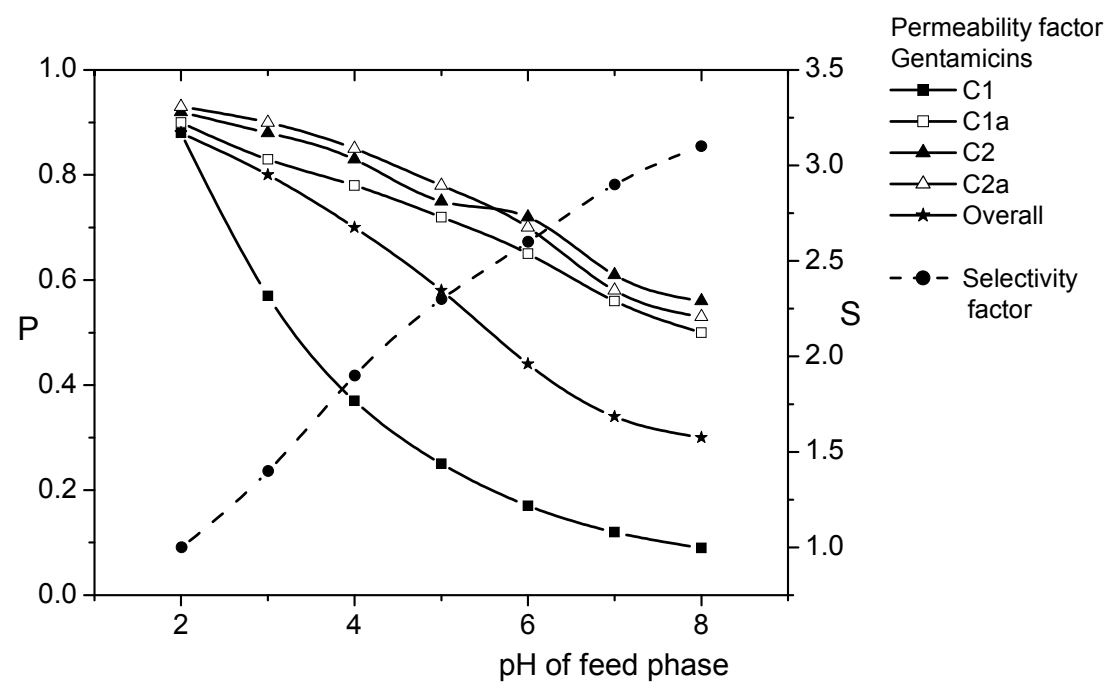

Fig. 8. Influence of $\mathrm{pH}$-value of feed phase on permeability and selectivity factors ( $\mathrm{pH}$ of stripping phase $=1.5$, D2EHPA concentration $=20 \mathrm{~g} / 1$, rotation speed $=500 \mathrm{rpm}$ )

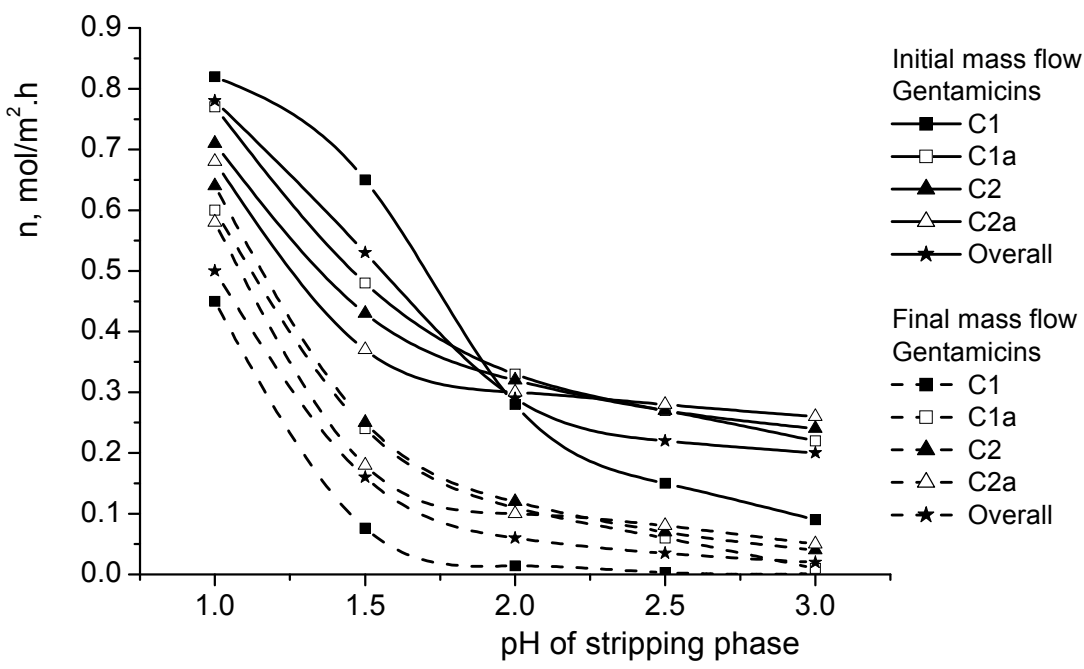

Fig. 9. Influence of $\mathrm{pH}$-value of stripping phase on mass flows of Gentamicins (pHof feed phase $=8$, D2EHPA concentration $=20 \mathrm{~g} / 1$, rotation speed $=500 \mathrm{rpm}$ )

At higher $\mathrm{pH}$-values of stripping phase, owing to the significant increase of the re-extraction efficiency of Gentamicins $C_{1 a}, C_{2}$ and $C_{2 a}$ compared to Gentamicin $C_{1}$, the order of the decrease of the initial mass flows is changed, the Gentamicin $C_{1}$ becoming the poorer extracted compound. The selectivity factor increases with the increase of $\mathrm{pH}$ of stripping phase and reaches the highest values for $\mathrm{pH}=3(\mathrm{~S}=10.8)$. This variation is in concordance 
with the above results and indicates that the lowest permeability through liquid membrane and the most significant negative influence of stripping phase $\mathrm{pH}$-value correspond to the pertraction of Gentamicin $\mathrm{C}_{1}$, due to the above discussed reasons.

The increase of carrier concentration into the liquid membrane induces the increase of the initial and final mass flows of all Gentamicins, but the basicity of the specific aminic groups controls the magnitude of this influence. According to the results obtained for reactive extraction of Gentamicins (Caşcaval et al., 2007), if the carrier exists in a stoechiometric deficit related to the complete reaction with all Gentamicins, it will firstly reacts with Gentamicin having the characteristic aminic group with the highest basicity, consequently with Gentamicin $C_{1}$. For this reason, the maximum difference between the initial mass flow of Gentamicin $C_{1}$ and those of the other Gentamicins is reached for the D2EHPA concentration below $20 \mathrm{~g} / 1$. Moreover, contrary to the variation of Gentamicin $C_{1}$ initial mass flow, the mass flows of Gentamicins $C_{1 a}, C_{2}$ and $C_{2 a}$ continuously increase without reaching any evident constant level in the domain 0- $60 \mathrm{~g} / 1 \mathrm{D} 2 \mathrm{EHPA}$.

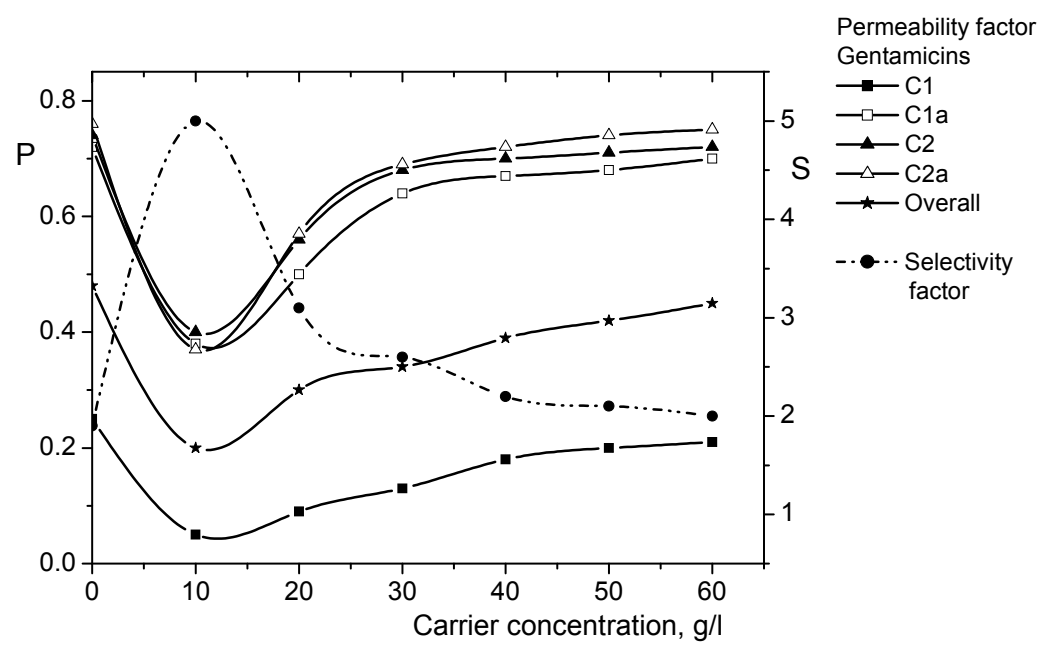

Fig. 10. Influence of carrier concentration on permeability and selectivity factors ( $\mathrm{pH}$ of feed phase $=8, \mathrm{pH}$ of stripping phase $=1.5$, rotation speed $=500 \mathrm{rpm}$ )

The variation of the selectivity factor with carrier concentration is opposite to that of the permeability factors (Figure 10). The maximum value of selectivity factor $(S=5)$ corresponds to the minimum of permeability factors, thus suggesting that at lower carrier concentration Gentamicin $C_{1}$ is less efficiently pertracted. The selectivity of pertraction is diminished for about 2.5 times by increasing the carrier concentration in the liquid membrane from 10 to $60 \mathrm{~g} / 1$.

Using the proper levels of the factors influencing the separation process ( $\mathrm{pH}$ of feed phase of $8, \mathrm{pH}$ of stripping phase of 3 , rotation speed of the feed and stripping phases below $100 \mathrm{rpm}$ and carrier concentration of $10 \mathrm{~g} / \mathrm{l}$ ), the most active Gentamicins (Gentamicins $\mathrm{C}_{1 \mathrm{a}}, \mathrm{C}_{2}$ and $\mathrm{C}_{2 \mathrm{a}}$ ) can be selectively pertracted from the initial mixture. By removing Gentamicin $\mathrm{C}_{1}$ from the biosynthetic mixture the biological activity of the antibiotic is enhanced and the therapeutic dose is reduced, its secondary effects being diminished. 


\section{Selective pertraction of carboxylic acids obtained by citric fermentation}

Citric acid is one of the widely used carboxylic acids, having multiple applications in chemical, pharmaceutical, food and cosmetic industries. This compound is mainly obtained through a fermentation process by Aspergillus niger cultivated on molasses (Moo-Young et al., 1985). Due to the presence in the final broth of other carboxylic acids as secondary metabolic products, especially malic and succinic acids, the separation and purification technology of citric acid is quite complicated. The citric acid represents about $80-95 \%$ from the total amount of organic acids in the broth at the end of fermentation, its concentration being of $50 \mathrm{~g} / 1$. The rest are secondary acids, their concentration reaching $4 \mathrm{~g} / 1$. At industrial scale, the separation and purification of citric acid consist on carboxylic acids precipitation as calcium salts, solubilization of calcium citrate by heating the solution and citric acid release by treating with sulfuric acid (Moo-Young et al., 1985). This technology needs high amount of raw materials and energy consumption and produces large amounts of calcium sulfate as the by-product, without leading to high purity of citric acid.

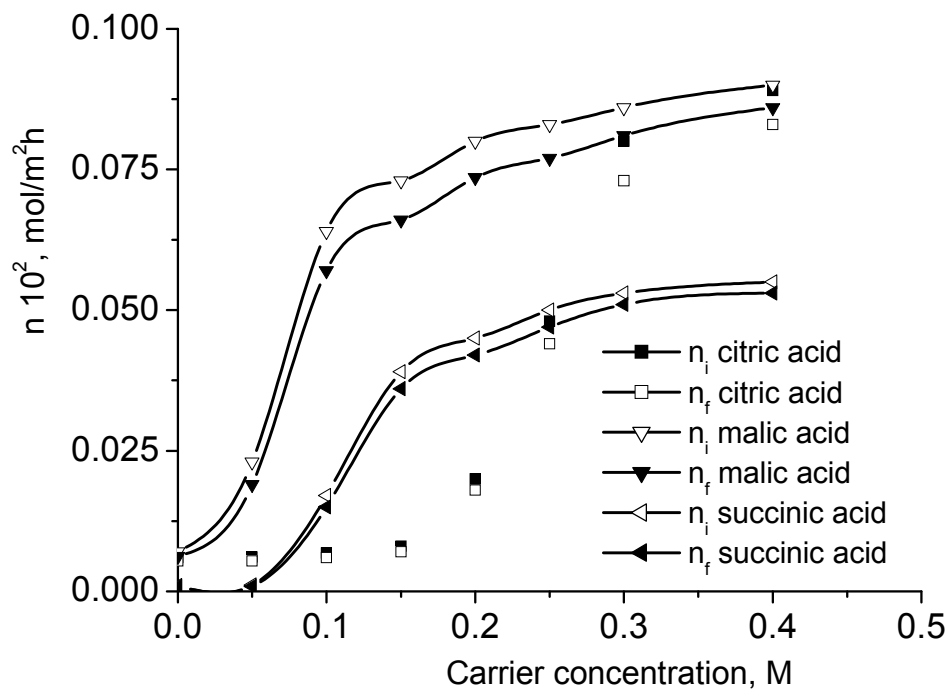

Fig. 11. Influence of carrier concentration on citric, malic and succinic acids mass flows (citric acid concentration in feed phase $=7.8 \times 10^{-2} \mathrm{M}$, malic acid concentration in feed phase $=$ $7.8 \times 10^{-2} \mathrm{M}$, succinic acid concentration in feed phase $=7.8 \times 10^{-2} \mathrm{M}$, rotation speed $=500 \mathrm{rpm}$, $\mathrm{pH}$ of feed phase $=3, \mathrm{pH}$ of stripping phase $=11$ )

Based on the differences between the extraction mechanisms, acidity of these carboxylic acids and hydrophobicity of the compounds formed with the carrier, the selective removal of the malic and succinic acids from the final fermentation broth by pertraction with Amberlite LA-2 has been performed (Caşcaval et al., 2004a). In the case of these acids pertraction from a mixture, the dependence of their mass flows on the $\mathrm{pH}$ gradient has been correlated with their acidity, because the acidity controls the rate of interfacial reactions between solute and carrier. Thus, the obtained order of the pertraction efficiency, given as follows: succinic acid<citric acid<malic acid, was the result of the higher acidity of citric and 
malic acids, on the one hand, and of the superior hydrophobicity of malic acid - Amberlite LA-2 complex, on the other hand.

The permeability factors of all studied acids tended to 1 with the increase of $\mathrm{pH}$-gradient, underlining the approach between the acid extraction and re-extraction yields. Moreover, the values of permeability factors suggest an inverse proportionality between the transport capacity of liquid membrane and the acidity of transferred solute, the order of permeability factors diminution being: succinic acid >malic acid>citric acid.

This order could be explain by the similar variation of the rate of interfacial reaction between acid - carrier compound and sodium hydroxide, the increase of acidity leading to the appearance of a kinetic resistance to the re-extraction process.

Concentration of Amberlite LA-2 inside of the liquid membrane induces a different influence on pertraction efficiency of the carboxylic acids. The difference on carrier effects is due to the difference on acids extraction mechanisms, as well as to the difference on solutes acidity and hydrophobicity. As it can be seen from Figure 11, by increasing the carrier concentration the malic acid, succinic acid and citric acid are successively pertracted.

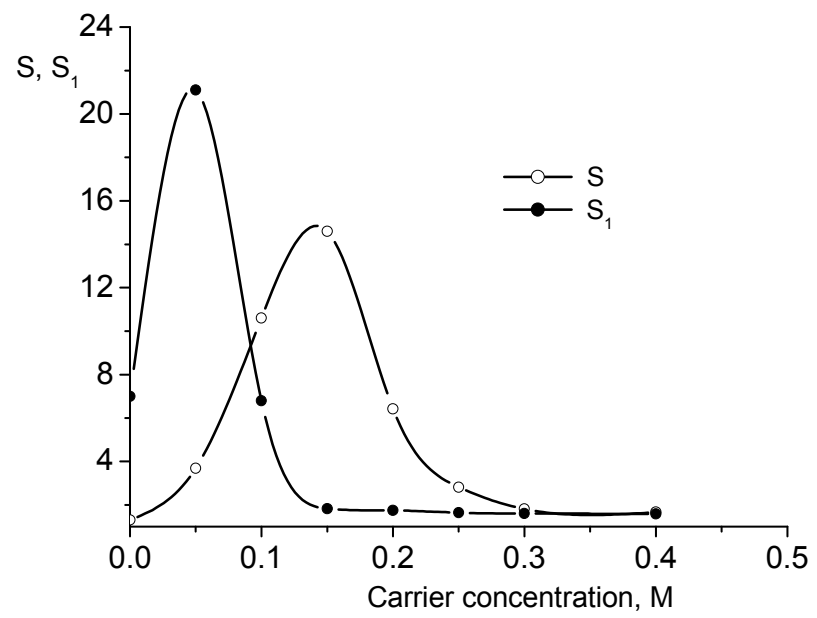

Fig. 12. Influence of carrier concentration on selectivity factors (citric acid concentration in feed phase $=7.8 \times 10^{-2} \mathrm{M}$, malic acid concentration in feed phase $=7.8 \times 10^{-2} \mathrm{M}$, succinic acid concentration in feed phase $=7.8 \times 10^{-2} \mathrm{M}$, rotation speed $=500 \mathrm{rpm}$ )

The succinic acid is extracted after the Amberlite LA- 2 concentration exceeds the value stoechiometrically needed for the interfacial reaction with malic acid, respectively after it exceeds the molar ratio between carrier and malic acid of 1 . The citric acid is extracted for carrier concentration higher than that corresponding to an equimolecular ratio with malic and succinic acids. Below the carrier concentrations that allow the reactive extraction of succinic and citric acids, their pertraction is possible only by physical solubilization in 1,2dichloroethane, but the acids mass flows are very low. These results demonstrate the major influence of the Amberlite LA-2 concentration on pertraction selectivity.

The above discussed results suggested the possibility to selectively remove the malic and succinic acids, the citric acid remaining in the raffinate phase. For confirming this hypothesis and establishing the required conditions for reaching a high selectivity of separation, the 
influences of $\mathrm{pH}$-gradient between the aqueous phases, carrier concentration and mixing intensity on pertraction selectivity have been studied. The selectivity of pertraction was described by means of the selectivity factors $S$ and $S_{1}$. The selectivity factor $S$ was introduced for the separation of malic and succinic acids from citric acid, and it was defined as the ratio between the sum of the final mass flows of malic and succinic acids and the final mass flow of citric acid. The factor $S_{1}$ was used for the separation of malic acid from succinic acid, being the ratio between the final mass flow of malic acid and that of citric acid.

The reduction of $\mathrm{pH}$ gradient leads to the increase of selectivity factors $S$ and $S_{1}$, but the magnitude of this effect is rather different. The modification of $\mathrm{pH}$ value of feed phase induces a stronger effect on separation selectivity of secondary carboxylic acids from citric acid, while the modification of stripping phase $\mathrm{pH}$ exhibits a more pronounced effect on separation selectivity of malic acid from succinic acid.

The decisive influence of carrier concentration on pertraction selectivity is underlined by the dependence between the selectivity factors and this parameter (Figure 12).

Similar to the variation of acids mass flows with carrier concentration, the experimental data show that the maximum selectivity both for separation of secondary carboxylic acids from citric acid, and for separation of malic acid from succinic acid is reached for an equimolecular ratio between Amberlite LA-2 and the pertracted acids.

In order to verify the above conclusions, initially the pertraction of citric, malic and succinic acids from a mixture similar to that obtained by citric fermentation was performed. The concentrations of the carboxylic acids in the feed solution were as follows: $50 \mathrm{~g} / 1(0.26 \mathrm{M})$ citric acid, $2.5 \mathrm{~g} / 1\left(2.1 \times 10^{-2} \mathrm{M}\right)$ malic acid, and $2.5 \mathrm{~g} / 1\left(1.9 \times 10^{-2} \mathrm{M}\right)$ succinic acid, respectively. In the second step, the malic acid was pertracted from a mixture containing $2.5 \mathrm{~g} / 1\left(2.1 \times 10^{-2}\right.$ M) malic acid and $2.5 \mathrm{~g} / 1\left(1.9 \times 10^{-2} \mathrm{M}\right)$ succinic acid. In both cases, the pertraction was carried out using the separation conditions that offer maximum selectivity and high rate of transport through liquid membrane: carrier concentration of $0.04 \mathrm{M}$, rotation speed of 500 $\mathrm{rpm}, \mathrm{pH}$ of feed phase of 4 and $\mathrm{pH}$ of stripping phase of 11 . The obtained results indicated that, by combining the favorable effects of pertraction parameters, superior values of selectivity factors can be obtained: $S=24.5, S_{1}=47.5$.

\section{Synergetic pertraction of $p$-aminobenzoic acid}

p-Aminobenzoic acid (PABA), also called vitamin $B_{10}$ or factor $R$, was found to be part of the folic acids. Because it is component of the pteroylglutamate, it is considered to act as provitamin for some bacteria and growth factor for some superior animals, in the human body possessing the capacity to synthesize folates. The most recent methods for PABA production are the chemical synthesis using methyl-4-formylbenzoate as the starting material or biosynthesis by mutant strains of E. coli (Amaratunga et al., 2000; Park et al., 2003). In both cases the separation stages are complex and require the consumption of a large amount of energy and materials.

Due to the insolubility of PABA in organic solvents immiscible with water, its separation by physical extraction is impossible. But, owing to the chemical structure of PABA which contains an acidic group, $-\mathrm{COOH}$, and a basic one, $-\mathrm{NH}_{2}$, the reactive extraction has been taken into consideration and has been performed using extractants of aminic and organophosphoric acid types, namely Amberlite LA-2 and (D2EHPA), respectively (Galaction et al., 2010). Because the formation of the third phase has been observed during the reactive extraction of PABA, the mechanisms and, consequently, the factors which 
control the mechanisms of acid extraction with the two extractants in presence of 1-octanol as phase modifier have been also investigated. On the basis of the experiments on the synergetic reactive extraction of PABA, the facilitated pertraction of this acid using a liquid membrane without and with 1-octanol has been comparatively analyzed from the viewpoint of the influences of the process parameters $(\mathrm{pH}$ gradient between the feed and stripping phases, carrier concentration, mixing intensity) (Kloetzer et al., 2010).
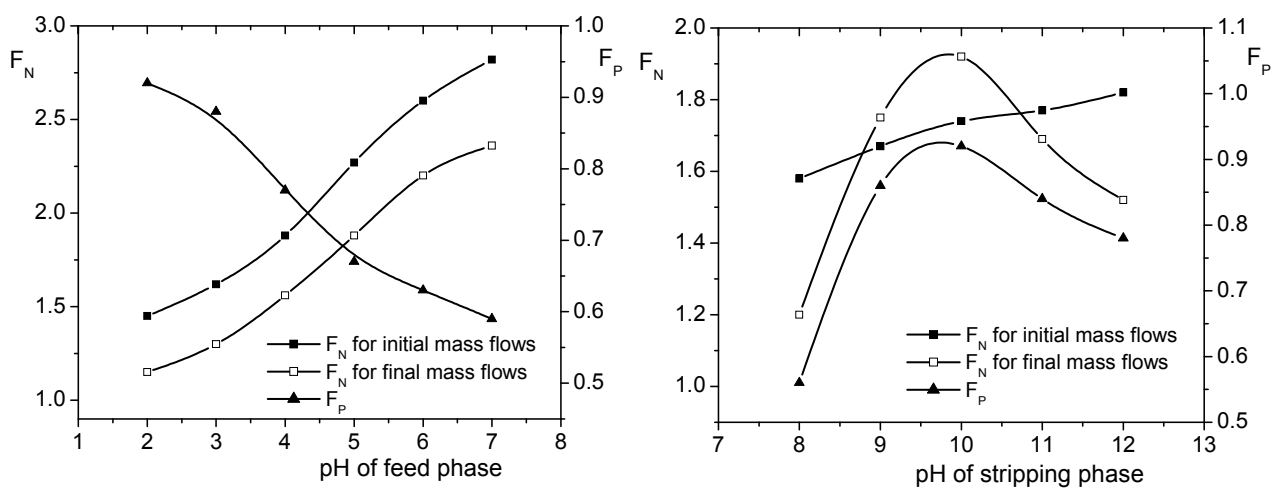

Fig. 13. Influence of $\mathrm{pH}$-values of feed and stripping phases on factors $\mathrm{F}_{\mathrm{N}}$ and $\mathrm{F}_{\mathrm{P}}$ (Amberlite LA-2 concentration $=40 \mathrm{~g} / \mathrm{l}$, rotation speed $=500 \mathrm{rpm}$, 1-octanol concentration $=10 \%$ vol.)

In order to quantify the effect of 1-octanol addition inside the liquid membrane on the initial and final mass flows, the factor $F_{N}$ has been considered and defined as the ratio between the mass flows recorded in presence and in absence of alcohol. Similarly, the factor $F_{P}$ has been calculated as the ratio between the permeability factors reached for liquid membrane with and without 1-octanol.

The dependence of the values of factors $\mathrm{F}_{\mathrm{N}}$ and $\mathrm{F}_{\mathrm{P}}$ on the feed phase $\mathrm{pH}$, plotted in Figure 13 , suggests that the addition of 1-octanol exhibits two different effects. The factor $F_{N}$, calculated either for the initial mass flows or for the final ones, is greater than the unit for the entire considered $\mathrm{pH}_{\mathrm{F}}$-domain and increases with the increase of $\mathrm{pH}_{\mathrm{F}}$. Thus, for $\mathrm{pH}_{\mathrm{F}}$ variation from 2 to $7, \mathrm{~F}_{\mathrm{N}}$ increased from 1.5 to 2.9 for the initial mass flows, respectively from 1.2 to 2.4 for the final mass flows. These results are the consequence of the favorable effect of 1-octanol on the solubilization of PABA molecules, free or bounded to the carrier molecules, on the membrane phase. The increase of $\mathrm{pH}_{\mathrm{F}}$ induces the dissociation of PABA in the feed phase, the presence of 1-octanol allowing also the extraction of the dissociated molecules of acid. The relative magnitude of the positive effect of alcohol addition is superior in the case of the initial mass flow, due to the supplementary kinetic resistance to the acid reextraction process from the membrane phase to the stripping solution.

Contrary, the values of factor $F_{P}$ are lower than 1 for the entire experimented domain of the feed phase $\mathrm{pH}$, the increase of $\mathrm{pH}_{\mathrm{F}}$ inducing the reduction of this factor. In this case, the significant increase of the initial mass flow of PABA by adding 1-octanol inside the liquid membrane exceeds the membrane capacity to transport the acid and to release it into the stripping phase.

Similar to the influence of $\mathrm{pH}_{\mathrm{F}}$, the factors $\mathrm{F}_{\mathrm{N}}$ are superior to 1 for all the considered $\mathrm{pH}_{\mathrm{S}}$ values, but the influence of $\mathrm{pH}_{\mathrm{S}}$ has to be distinctly analyzed for the initial and final mass 
flows ratios. Thus, the factor $\mathrm{F}_{\mathrm{N}}$, calculated as the ratio between the initial mass flows, increased slowly with the increase of stripping phase $\mathrm{pH}$, from 1.6 to 1.8. The variation of factor $\mathrm{F}_{\mathrm{N}}$ related to the final mass flows with $\mathrm{pH}_{\mathrm{S}}$ indicated its increase to a maximum level, corresponding to $\mathrm{pH}_{\mathrm{S}}=10$, followed by its decrease. The maximum $\mathrm{F}_{\mathrm{N}}$ (1.9) exceeded that obtained for the initial mass flows indifferent of $\mathrm{pH}_{\mathrm{S}}$-value, due to the more important influence of $\mathrm{pH}_{\mathrm{S}}$ on the PABA reextraction step from the membrane phase.

The variation of $F_{P}$ follows that of $F_{N}$ calculated for the final mass flows, the two factors being directly correlated. Moreover, for the entire investigated domain of stripping phase $\mathrm{pH}$, the value of $\mathrm{F}_{\mathrm{P}}$ was lower than 1 (maximum $\mathrm{F}_{\mathrm{P}}$ was 0.92 ).

Due to its favorable effect on PABA extraction from the feed phase into the liquid membrane, the addition of 1-octanol in dichloromethane induces the increase of the initial and final mass flows of the acid. Thus, for $40 \mathrm{~g} / 1$ Amberlite LA-2 and alcohol concentration variation from 5 to $20 \%$ vol., the initial mass flow was amplified for about 1.4-2.2 times and the final mass flow for about 1.1-1.6 times compared with the corresponding mass flows in absence of 1-octanol (Caşcaval et al., 2009). This effect is more significant for the initial mass flow, because the reextraction rate tended to its maximum level for the given experimental conditions. For the same reason, the permeability factor was increased slowly from 0.4 to 0.7 by increasing the alcohol concentration inside the membrane phase.

\section{Selective pertraction of cinnamic acids}

Cinnamic acid, also known as phenylacrylic acid, is a natural compound derived from phenylalanine, its main vegetable sources being the cinnamon, the resin of Liquidambar tree, the storax, the balsam of tolu, and the balsam of Peru. The main utilization of cinnamic acid is in the cosmetic/perfumery industry, especially as methyl, ethyl or benzyl esters (the cinnamic acid and its volatile benzylic ester are responsible for the cinnamon flavor). The cinnamic acid itself, or the p-hydroxy- and p-methoxycinnamic acids, has different pharmaceutical applications, for pulmonary affections, cancer, lupus, infectious diseases (diarrhea, dysentery), possessing antibacterial and antifungal activity (Saraf \& Simonyan, 1992; Tawata et al., 1996; Lee et al., 2004). It is also used in food, or for the synthetic ink, resins, elastomers, liquid crystalline polymers and adhesives production.

The cinnamic acids could be obtained by extraction from vegetable materials, by chemical synthesis or biosynthesis. New methods have been recently developed for cinnamic acid extraction (supercritical fluid extraction, vapor phase extraction, pressurized fluid extraction), but their applications are rather limited for high quantities of vegetable materials (Bartova et al., 2002; Palma et al., 2002; Smelz et al., 2004; Naczk \& Shahidi, 2004). The cinnamic acid is synthesized from styrene and carbon tetrachloride, by oxidation of cinnamic aldehyde, or from benzyl dichloride and sodium acetate. The chemical methods are expensive due to the costs of the starting materials, the high number of required stages for product purification, and generated large amounts of unwanted secondary products. For these reasons, the production by fermentation or/and enzymatic methods of cinnamic acid and its main derivatives, the p-hydroxy- and p-methoxycinnamic acids, have been developed. Thus, Saccharomyces cerevisiae, Escherichia coli, Pseudomonas sp. have been cultivated on glucose, and Cellulomonas galba on n-paraffins with addition of alkylbenzenes (Parales et al., 2002). The glucose, fructose, lactose, sugar, cellulose and starch can be enzymatically transformed by phenylalanine ammonia lyase or tyrosine ammonia lyase in alkaline media. These enzymes are synthesized directly into the media by the mutant strains 
of E. coli, Rhodotorula sp., Rhodosporidium sp., Sporobolomyces sp., Rhizoctonia solani, Trichosporon cutaneum, Rhodobacter sp. (Hanson \& Havir, 1981; Naczk \& Shahidi, 2004).

Excepting from our works, there are no reports on the possibility of separating cinnamic acid and its related acids from fermentation broths or enzymatic media by liquid-liquid extraction. This is probably due to the low solubility of these compounds in solvents immiscible with water. Their extraction became possible by adding an extractant of aminic type into the solvent, this compound reacting with the cinnamic acids and leading to the formation of hydrophobic derivatives (Camarut et al., 2006). This technique has been considered for developing the cinnamic and p-methoxycinnamic acids selective pertraction with Amberlite LA-2 (Galaction et al., 2007). Due to the methoxy group which differentiates the two studied acids, the influence of the feed phase $\mathrm{pH}$ is based on two different mechanisms. Thus, from Figure 14, plotted for $\mathrm{pH}$ of stripping phase of 10, it can be observed that the initial and final mass flows of the cinnamic acid are continuously reduced with the increase of $\mathrm{pH}$-value. On the other hand, the mass flows of $\mathrm{p}$-methoxycinnamic acid initially increase with the $\mathrm{pH}$ increase, reach a maximum level at $\mathrm{pH}=4$, decreasing then. This variation is more pronounced for the initial mass flow.

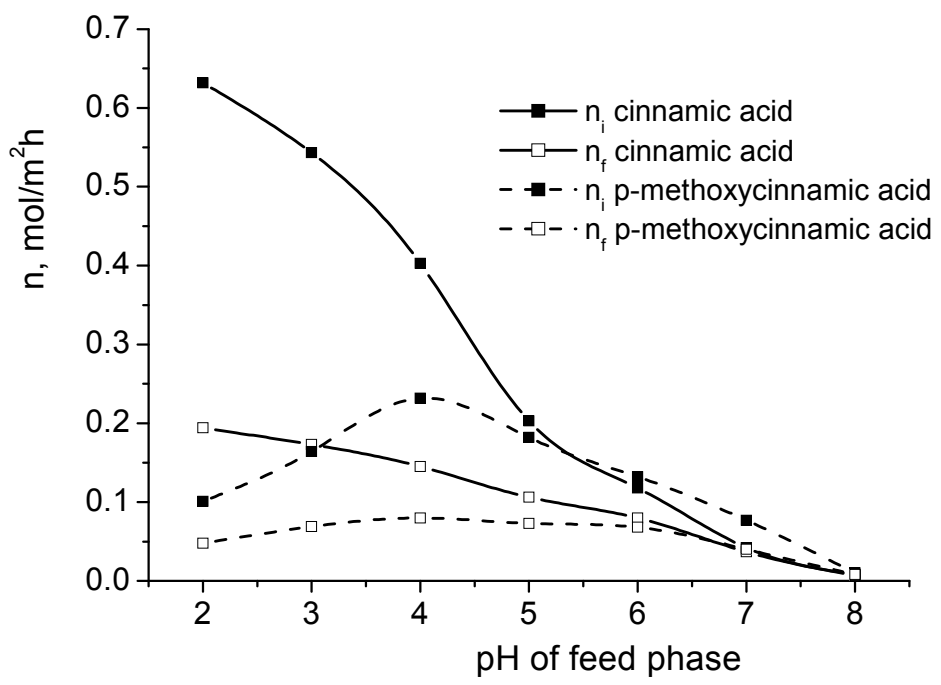

Fig. 14. Influence of $\mathrm{pH}$-value of feed phase on mass flows of cinnamic and p-methoxycinnamic acids ( $\mathrm{pH}$ of stripping phase $=10$, Amberlite LA- 2 concentration $=40 \mathrm{~g} / \mathrm{l}$, rotation speed $=500 \mathrm{rpm})$

These variations are the result of the mechanism of reactive extraction of the two acids. The reactive extraction occurs by means of the interfacial interactions between the carboxylic groups of the cinnamic and p-methoxycinnamic acids and Amberlite LA-2. These interactions could be of hydrogen bonding type with the undissociated carboxylic groups, or of ionic type, if the acids dissociate in the aqueous solution. The initial mass flow of cinnamic acid continuously decreased with the $\mathrm{pH}$ increase due to its dissociation at higher $\mathrm{pH}$-values. The existence of the maximum level of the initial mass flow of $\mathrm{p}$ methoxycinnamic acid is the result of two opposite phenomena occurring with the $\mathrm{pH}$ 
increase: the diminution of the methoxy group protonation, this promoting the extraction, and the dissociation of the carboxylic group, with negative effect on extraction.

For $\mathrm{pH}$-values bellow 5, the initial mass flow of cinnamic acid exceeded that of pmethoxycinnamic acid. Over $\mathrm{pH}=5$, due to the superior hydrophobicity and acidity of $\mathrm{p}$ methoxycinnamic acid, its initial mass flow becomes higher than that of cinnamic acid $(\mathrm{pKa}=4.44$ for cinnamic acid, $\mathrm{pKa}=4.28$ for $\mathrm{p}$-methoxycinnamic acid (Weast, 1974)). But, for the pertraction process, the differences between the mass flows of the two acids recorded for $\mathrm{pH}>5$ are less pronounced than in the case of reactive extraction. This result is the consequence of the less intense mixing in the pertraction system, and, therefore, of the resistance to the diffusion through the boundary layers from liquid membrane interfaces, which is more important than that induced for the reactive extraction process, especially for the compounds with higher molecular weight. Among the two acids, the resistance to the diffusion of p-methoxycinnamic acid is higher, due to its more voluminous molecule.

The variations of the two acids final mass flows are similar to those of the initial mass flows, owing to their direct dependence to the acids concentrations in the organic layer.

The permeability factor of cinnamic acid increases with the $\mathrm{pH}$ increase, this variation suggesting that the reduction of its initial mass flow exhibits a positive effect on the permeability through liquid membrane, due to the diminution of the amount of acid accumulated into the organic phase (Figure 15). Thus, the maximum value of permeability factor for the considered experimental conditions was of 0.93 , being reached at $\mathrm{pH}=8$.

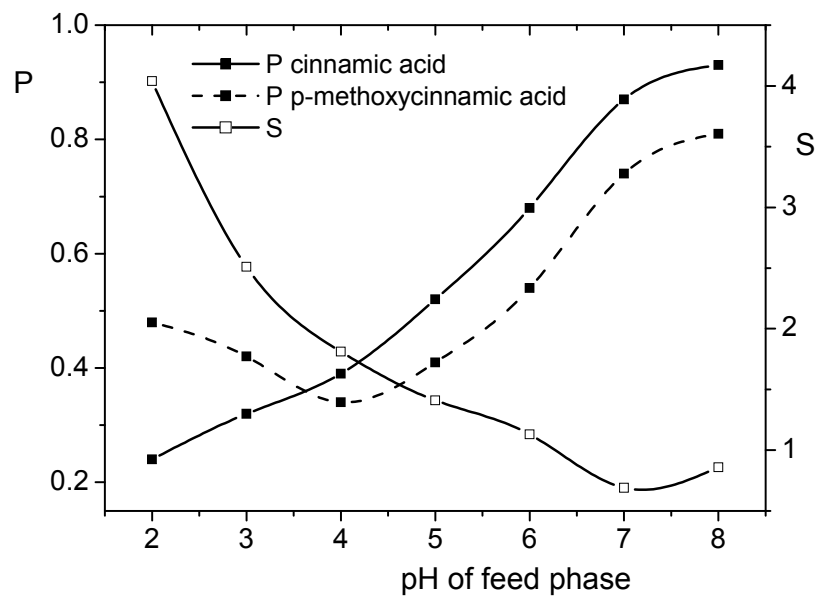

Fig. 15. Influence of $\mathrm{pH}$-value of feed phase on permeability and selectivity factors ( $\mathrm{pH}$ of stripping phase $=10$, Amberlite LA-2 concentration $=40 \mathrm{~g} / 1$, rotation speed $=500 \mathrm{rpm}$ )

The permeability factor of $\mathrm{p}$-methoxycinnamic acid has a particular evolution with the $\mathrm{pH}$ increase. This parameter initially decreases and reaches a minimum level at $\mathrm{pH}=4$, then increasing similarly as for cinnamic acid. For $\mathrm{pH}<4$, the increase of the amount of $\mathrm{p}$ methoxycinnamic acid extracted in organic layer exceeds the increase of its final mass flow, due to the high initial mass flow. Because the initial mass flow of p-methoxycinnamic acid is lower comparatively to cinnamic acid, its permeability factor is superior to that of cinnamic acid in this domain of $\mathrm{pH}$. For higher $\mathrm{pH}$-values, due to the resistance to the diffusion from 
the liquid membrane to the stripping phase, which is more important for pmethoxycinnamic acid, the permeability factor of this acid becomes lower than that of cinnamic acid.

For describing the selectivity of pertraction, the selectivity factor, $\mathrm{S}$, has been defined as the ratio between the final mass flow of cinnamic acid and that of p-methoxycinnamic acid. From Figure 15 it can be seen that the maximum value of selectivity factor is reached at the $\mathrm{pH}$ of feed phase of 2, as the result of the highest difference between the acids extraction degree and, consequently, between their concentrations in the liquid membrane. The increase of $\mathrm{pH}$ induces a negative effect on the selectivity of cinnamic acid separation. Thus, for $\mathrm{pH}>6$, the selectivity factor is less than 1 , owing to the higher amount of $\mathrm{p}$ methoxycinnamic acid in the liquid membrane and higher final mass flow compared to those of cinnamic acid.

The increase of carrier concentration into the liquid membrane induces the increase of the initial and final mass flows of both acids. At the concentration of Amberlite LA-2 bellow 10 $\mathrm{g} / \mathrm{l}$, the initial mass flow of p-methoxycinnamic acid is higher, due to its superior acidity compared with cinnamic acid. The increase of Amberlite LA-2 amount in the organic phase exhibits a more pronounced effect on cinnamic acid mass flow, because it compensates the lower acidity of this acid. This phenomenon cumulated with the slower diffusion of $\mathrm{p}$ methoxycinnamic acid generates significant differences between the values of acids mass flows for carrier concentrations over $10 \mathrm{~g} / 1$. The initial mass flows of the acids reach a constant level at $40 \mathrm{~g} / 1$ Amberlite LA-2. The variation of the final mass flows is similar, the constant level being reached for Amberlite LA-2 concentration of $60 \mathrm{~g} / 1$.

The evolution of the acids permeability factors are different. Similar to the pertraction of carboxylic acids obtained by citric fermentation, they initially decrease from a value corresponding to the absence of Amberlite LA-2 in the organic solvent to a minimum value for a concentration of $10 \mathrm{~g} / 1$ Amberlite LA-2 and finally increase concomitantly with the carrier concentration.

The positive influence of the increase of carrier concentration is more important in the case of cinnamic acid, this leading to the increase of the selectivity factor from 0.6 for free pertraction to 2 for facilitated pertraction with $40 \mathrm{~g} / 1$ Amberlite LA-2. For higher carrier concentration, the selectivity factor remains at the constant level.

\section{Fractionation of amino acids mixture by pertraction}

The amino acids can be obtained by biosynthesis, by protein hydrolysis or by extraction from natural sources. The most efficient methods are the first two, but the separation of amino acids from fermentation broths or protein hydrolysates is rather difficult. In the last decades a continuous and increasing interest has been observed in developing the techniques that can improve the selectivity and the yield of downstream processes for the separation and purification of amino acids (Liu \& Dai, 2003). The separation techniques currently applied for removal and purification of amino acids from dilute aqueous solutions typically employ the ion exchange, crystallization at the isoelectric point or chromatography (Caşcaval et al., 2004b). But, these techniques are rather difficult to be transposed to the industrial scale, thus affecting the production of amino acids and increasing the cost of the used technology.

The reactive extraction became a very attractive method for amino acids separation, because it offers an advantageous alternative to the above mentioned separation techniques. Amino 
acids dissociate in aqueous solutions, forming characteristic ionic species as a function of the solution $\mathrm{pH}$-value. This property makes amino acids hydrophilic at all $\mathrm{pH}$-values and, thus, complicates their recovery by solvent extraction. For this reason, the amino acids solubility in conventional organic solvents is lower, their physical extraction being practically impossible. The liquid-liquid extraction of amino acids becomes possible only by adding extractants into the organic phase, namely derivatives of phosphoric acid (Kelly et al., 1998; Liu et al., 1999; Caşcaval et al., 2001; Juong \& Wang, 2002; Lin et al., 2006; Lin \& Chen, 2006), high molecular weight amines (Rehm \& Reed, 1993; Schugerl, 1994; Tan et al., 2007) or some types of crown-ethers (Deblay et al., 1990).

The pertraction could be also used for amino acids separation, the proper carrier being chosen from the above listed extractants (organophosphoric acid, high molecular weight amines or crown-ethers). In this context, the separation of some amino acids of acidic character (L-aspartic acid, L-glutamic acid), basic character (L-histidine, L-lysine, L-arginine) or neutral character (L-glycine, L-tryptophan, L-cysteine, L-alanine) from their mixtures obtained either by fermentation or protein hydrolysis using the facilitated pertraction with D2EHPA in dichloromethane has been analyzed (Blaga et al., 2008).

In the case of amino acids pertraction, the influence of the $\mathrm{pH}$-gradient between the phases is enhanced by the formation of the ionized forms of amino acids in the aqueous phases and controls both the efficiency of extraction/reextraction and the transport rate through the solvent layer. Thus, from Figure 16 it can be observed that for all studied amino acids the initial mass flows increase with the increase of feed phase $\mathrm{pH}$, reach a maximum value followed by their strong decrease.
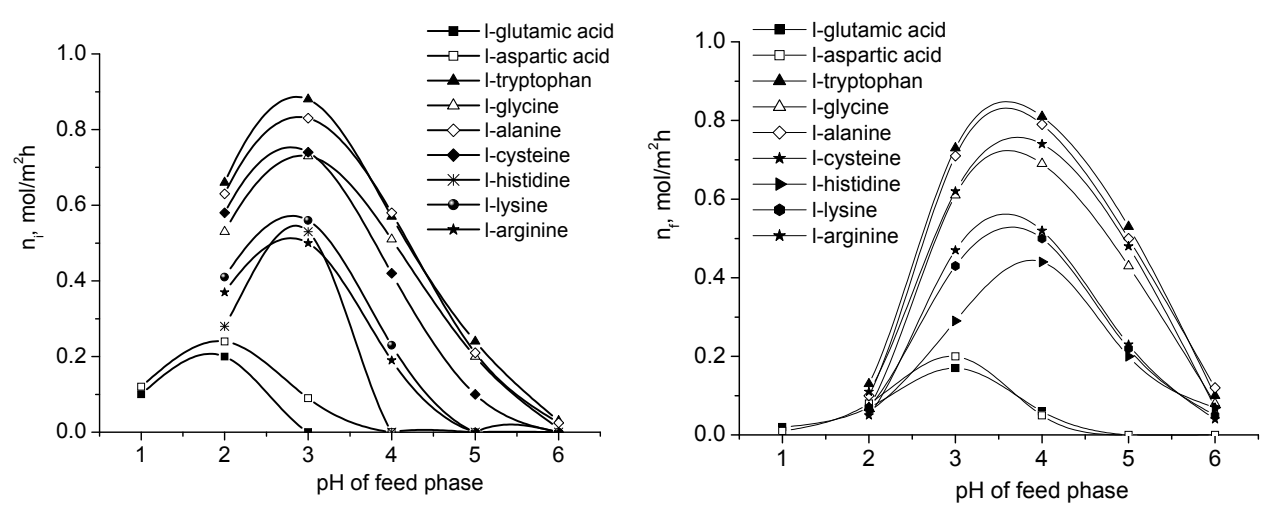

Fig. 16. Influence of $\mathrm{pH}$ value of feed phase on mass flows of amino acids ( $\mathrm{pH}$ of stripping phase $=2$, carrier concentration $=40 \mathrm{~g} / 1$, rotation speed $=500 \mathrm{rpm}$ )

The value of the $\mathrm{pH}$ corresponding to the maximum initial mass flows is 2 for the acidic amino acids, and 3 for the other amino acids. This influence of the $\mathrm{pH}$ value on amino acids mass flows is the consequence of the reactive extraction mechanism of amino acids with D2EHPA, which occurs by means of an interfacial chemical reaction of the ion exchange type controlled by the $\mathrm{pH}$ of aqueous phase. According to the obtained results by studying the amino acids reactive extraction (Caşcaval et al., 2001), the carrier, D2EHPA, reacts only if the amino acids exist in aqueous solution in their cationic forms $(\mathrm{pH}$ of aqueous phase has

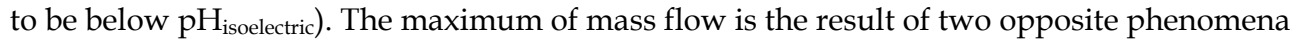


which occur with the $\mathrm{pH}$ increase: the increase of the concentration of extractant active form (in the strong acidic $\mathrm{pH}$-domain the extractant is protonated and, consequently, becomes unable to react with the amino acid), and the decrease of the total amount of amino acid existing in cationic form. The further increase of the $\mathrm{pH}$-value of feed phase leads to the increase of the concentration of the acidic and neutral amino acids zwitterions, and respectively, of the basic amino acids dication-anionic species or zwitterions, thus reducing significantly the initial mass flows of the amino acids (at the isoelectric point the reactive extraction of amino acids becomes impossible (Caşcaval et al., 2001)). Unlike the acidic or neutral amino acids, the pertraction of basic amino acids is not possible even if the $\mathrm{pH}$ values are lower than those corresponding to their isoelectric points, due to the formation of the dication-anionic species (L-histidine: $\mathrm{n}_{\mathrm{i}}=0$ for $\mathrm{pH}_{\mathrm{i}} \geq 4$, L-lysine: $\mathrm{n}_{\mathrm{i}}=0$ for $\mathrm{pH}_{\mathrm{i}} \geq 5$, Larginine: $\mathrm{n}_{\mathrm{i}}=0$ for $\mathrm{pH}_{\mathrm{i}} \geq 5$ ).

The recorded differences between the initial mass flows of the solutes are probably the result of the different hydrophobicity of the radicals $\mathrm{R}$ from the amino acids structures, this being in concordance with the previous conclusions regarding the reactive extraction yields of the same amino acids with D2EHPA (Caşcaval et al., 2001).

The final mass flows of amino acids initially increase with $\mathrm{pH}$ of the feed phase, owing to their accumulation in the liquid membrane, reaching the maximum values at $\mathrm{pH}_{\mathrm{i}}=3$ for aspartic and glutamic acids, and at $\mathrm{pH}_{\mathrm{i}}=4$ for the rest of amino acids, respectively. Because the amino acids are accumulated in the liquid membrane in different proportions, the differences between the final mass flows are rather similar to those between the initial mass flows. The further increase of $\mathrm{pH}_{\mathrm{i}}$ to the neutral $\mathrm{pH}$-domain leads to the decrease of the final mass flows, owing to the change of the direction of $\mathrm{pH}$-gradient which controls the direction of solute transfer through the liquid membrane.

For all considered amino acids, the permeability factors strongly increase with the $\mathrm{pH}$ increase, becoming higher than 1 for $\mathrm{pH} \geq 3$. This variation indicates that the final mass flows become larger than the initial ones, phenomenon that is possible due to the reextraction of the additional amount of amino acids accumulated into the organic layer.

The increase of the $\mathrm{pH}$-value of the stripping phase caused the reducing of both initial and final mass flows of the amino acids that can be extracted at the prescribed $\mathrm{pH}$ of feed phase. For example, although at $\mathrm{pH}_{\mathrm{i}}=2$ all the amino acids are extracted, at $\mathrm{pH}_{\mathrm{i}}=4$ the initial mass flows of L-aspartic acid, L-glutamic acid and L-histidine are 0, for the above presented reasons.

A similar variation has been recorded also for the permeability factors as a function of the $\mathrm{pH}$ value of stripping phase (Figure 17). The maximum values of the permeability factors are reached for the $\mathrm{pH}$-value of stripping phase of 1 . This result, together with the variations of mass flows, indicated that by increasing the $\mathrm{pH}_{\mathrm{f}}$, the direction of the solutes transport through liquid membrane is inverted, and consequently the amount of the accumulated amino acids inside the solvent layer increases significantly.

According to the Figure 17, the maximum values of the permeability factors are higher for L-aspartic and L-glutamic acids, owing both to their lower initial mass flows, and to their lower hydrophobicity, which promote the reextraction in the stripping phase.

Therefore, by combining the feed phase $\mathrm{pH}$-value, which strongly limits the amino acids transfer to the membrane phase, the $\mathrm{pH}$-value of stripping phase, which controls the rate of the amino acids re-extraction from the liquid membrane and, consequently, their concentration gradients between the two aqueous phases, the carrier concentration, which 
controls the capacity of liquid membrane to transport the solute, and the mixing intensity, which can selectively diminish the resistance to the diffusion, the selective separation by facilitated pertraction becomes possible for different groups of amino acids with similar acidic properties. Therefore, for $\mathrm{pH}$ of feed phase over 5 only L-glycine, L-alanine, Ltryptophan and L-cysteine are pertracted, for $\mathrm{pH}$ of feed phase between 4 and 5 these amino acids and L-lysine and L-arginine, for $\mathrm{pH}$ of feed phase between 3 and 4 L-histidine can be added to the previous list of pertracted amino acids, and below $\mathrm{pH}$ of $3 \mathrm{~L}$-aspartic acid and L-glutamic acid can be also separated.
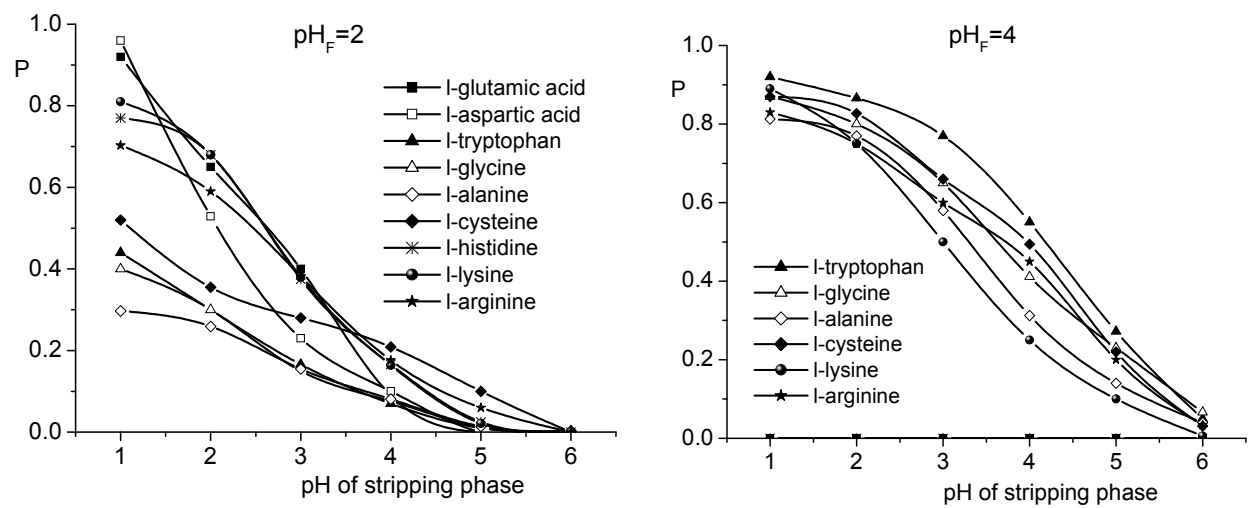

Fig. 17. Influence of $\mathrm{pH}$-value of stripping phase on permeability factors (carrier concentration $=40 \mathrm{~g} / \mathrm{l}$, rotation speed $=500 \mathrm{rpm}$ )

\section{Conclusions}

Extraction and transport through liquid membranes, also called pertraction, constitutes advantageous alternative to the conventional separation methods, because it reduces the number of stages required for an efficient separation and, therefore, the corresponding energy and material consumption. For these reasons, this technique has a considerable potential for biosynthetic products separation and purification, being required for further development of many biotechnologies, and represents very attractive research domain for chemical and biochemical engineers. In the actual context of the "white biotechnology", the studies in the field of bioseparations are dedicated to extending the application area of pertraction for including the separation of other biosynthetic or natural products and to scaling-up this technique at industrial level.

\section{References}

Amaratunga, M.; Lobos, J. H.; Johnson, B. F. \& Wiliams, E. D (2000). Genetically engineered microorganisms and method for producing 4-hydroxybenzoic acid. Patent US 6030819/2000

Baird, M.H.I. (1991). Solvent extraction - the challenge of a "mature" technology. The Canadian Journal of Chemical Engineering, Vol.69, No.6, 1287-1301, ISSN 1939019X 
Bartova, M.; Opletal, L.; Chobot, V. \& Sovova, H. (2002). Liquid chromatographic analysis of supercritical carbon dioxide extracts of Schizandra chinensis. Journal of Chromatography B: Analytical Technologies in the Biomedical and Life Science, Vol.770, No.1-2, pp. 283-288, ISSN 1570-0232

Blaga, A.C.; Galaction, A.I. \& Caşcaval, D. (2008). Separation of amino acids from their mixture by facilitated pertraction with D2EHPA. Chemical and Biochemical Engineering Quarterly, Vol.22, No.4, pp. 439-446, ISSN 0352-9568

Camarut, M.; Galaction, A.I. \& Caşcaval, D. (2006). Separation of trans-cinnamic acid by reactive extraction in low-polar solvent. Romanian Biotechnological Letters, Vol.11, No.5, pp. 2897-2903, ISSN 1224-5984

Caşcaval, D. \& Galaction, A.I. (2004). New extraction techniques in bioseparation 1.Reactive extraction. Chemical Industry Journal, Vol.58, No.9, pp. 375-386

Caşcaval, D. \& Galaction, A.I. (2007). The European colour of biotechnology is white. Romanian Biotechnological Letters, Vol.12, No.6, pp. 3489-3494, ISSN 1224-5984

Caşcaval, D.; Galaction, A.I. \& Nicuță, N. (2006). Separarea eritromicinei prin pertractie libera si facilitata. Revista de Chimie, Vol. 57, No.3, pp. 297-302, ISSN 0034-7752

Caşcaval, D.; Galaction, A.I. \& Oniscu, C. (2004a). Selective pertraction of carboxylic acids obtained by citric fermentation. Separation Science and Technology, Vol.39, No.8, pp. 1907-1925, ISSN 0149-6395

Caşcaval, D.; Galaction, A.I. \& Turnea, M. (2009). Study of the influence of solute and carrier characteristics on facilitated pertraction mechanism in pseudosteady-state conditions. Journal of Membrane Science, Vol.328, No.1-2, pp. 228-237, ISSN 0376-7388

Caşcaval, D.; Galaction, A.I.; Nicuță, N. \& Blaga, A.C. (2007). Selective separation of gentamicins from the biosynthetic mixture by reactive extraction. Separation and Purification Technology, Vol. 57, No.2, pp. 264-269, ISSN 1383-5866

Caşcaval, D.; Oniscu, C. \& Caşcaval, C. (2000). Selective Separation of Penicillin V from Phenoxyacetic Acid Using Liquid Membranes. Biochemical Engineering Journal, Vol.5. No.1, pp. 45-50, ISSN 1369-703X

Caşcaval, D.; Oniscu, C. \& Galaction, A.I. (2001). Selective Separation of Amino Acids by Reactive Extraction. Biochemical Engineering Journal. Vol. 7, No.3, pp. 171-176, ISSN 1369-703X

Caşcaval, D.; Oniscu, C. \& Galaction, A.I. (2004b). Biochemical engineering and biotechnology. 3. Bioseparations, Performantica, ISBN 973-99683-3-3, Iasi, Romania

Daugherty, E. (2006). Biotechnology: Science for the new millennium, EMC Paradigm Publishing, ISBN 0-763822828, New York, USA

Deblay, P.; Minier, M. \& Renon, H. (1990). Separation of L-valine from fermentation broths using a supported liquid membrane. Biotechnology and Bioengineering, Vol.35, pp. 123-131, ISSN 1097-0290

Fortunato, R.; Afonso, C.A.M.; Reis, M.A. \& Crespo, J.G. (2004). Supported liquid membranes using ionic liquids: study of transport mechanisms and stability. Journal of Membrane Science, Vol.242, No.1, pp. 197-204, ISSN 03767388

Galaction A.I.; Kloetzer, L. \& Caşcaval, D. (2010). Separation of p-aminobenzoic acid by reactive extraction in the presence of 1 -octanol as phase modifier. Chemical and 
Biochemical Engineering Quarterly, Vol.24, No.2, pp. 149-157, ISSN 03529568

Galaction, A.I. \& Caşcaval, D. (2006). Secondary metabolites with pharmaceutical, cosmetic and food applications, Casa de Editura Venus, ISBN 973-756-000-0, Iaşi, Romania

Galaction, A.I.; Camarut, M. \& Caşcaval, D. (2007). Selective separation of cinnamic and pmethoxycinnamic acids by facilitated pertraction. Separation Science and Technology, Vol.42, No.16, pp. 3727-3740; ISSN 0149-6395

Galaction, A.I.; Caşcaval, D. \& Nicuță, N. (2008). Selective removal of Gentamicin C $_{1}$ from biosynthetic Gentamicins by facilitated pertraction for increasing antibiotic activity. Biochemical Engineering Journal, Vol.42, No.1, pp. 28-33, ISSN 1369$703 \mathrm{X}$

Galaction, A.I.; Nicuță, N. \& Caşcaval, D. (2009). Separarea eritromicinei prin pertracție directă din lichide de fermentație simulate. Revista Medico-Chirurgicala, Vol.113, No.2, pp. 619-624, ISSN 0048-7848

Hanson, K.R. \& Havir, E.A. (1981). The Biochemistry of Plants, Vol. 7, Academic Press, ISBN 0-12-67407-1, New York, USA

Isoherranen, N. \& Soback, S. (2000). Determination of gentamicin after trimethylsilylimidazole and trifluoroacetic anhydride derivatization using gas chromatography and negative ion chemical ionization ion trap mass spectrometry. Analyst, Vol.125, pp. 1573-1576, ISSN 0003-2654

Juang, R.S.; Lee, S.H. \& Shiau, R.C. (1998). Carrier-facilitated liquid membrane extraction of penicillin $G$ from aqueous streams. Journal of Membrane Science, Vol.146, No.1, pp. 95-101, ISSN 0376-7388

Juong, R.-S., Wang, Y.-Y.: Amino acids separation with D2EHPA by solvent extraction and liquid surfactant membranes. Journal of Membrane Science. Vol.207, No.2, pp. 241-246, ISSN 0376-7388

Kang, C.D. \& Sim, S.J. (2008). Direct extraction of astaxanthin from Haematococcus culture using vegetable oils. Biotechnology Letters Vol.30, No.3, pp. 441-444, ISSN 1573-6776

Katikaneni, S.P.R. \& Cheryan, M. (2002). Purification of fermentation-derived acetic acid by liquid-liquid extraction and esterification. Industrial \& Engineering Chemistry Research, Vol.41, No.11, pp. 2745-2752, ISBN 1520-5045

Kawasaki J.; Egashira R.; Kawai T.; Hara H. \& Boyadzhiev L. (1996). Recovery of erythromycin by a liquid membrane. Journal of Membrane Science Vol.112, No.2, pp. 209-217, ISSN 0376-7388

Kelly, N.A.; Lukhezo, M.; Reuben, B.G.; Dunne, L.J. \& Verrall, M.S. (1998). Reactive solvent extraction of amino acids with cationic extractants. Journal of Chemical Technology \& Biotechnology, Vol.72, pp. 347-355, ISSN 0268-2575

Kislik, V.S. (2010). Liquid membranes - principles and applications in chemical separations and wastewater treatment, Elsevier, ISBN 978-0-444-53218-3, London, UK

Kloetzer, L.; Galaction, A.I. \& Caşcaval, D. (2010). Facilitated pertraction of paminobenzoic acid with Amberlite LA-2 in presence of 1-octanol. Separation Science and Technology Vol.45, No.10, pp. 1440-1447, ISSN 0149-6395 
Korzybski, T. (1978). Antibiotics: origin, nature and properties, American Society for Microbiology, ISBN-091482614X, Washington, USA

Lee, S.; Han, J.M.; Kim, H.; Kim, E.; Jeong, T.S.; Lee, W.S. \& Cho, K.H. (2004). Synthesis of cinnamic acid derivatives and their inhibitory effects on LDL-oxidation, acylCoA: cholesterol acyltransferase-1 and -2 activity, and decrease of HDL-particle size. Bioorganic \& Medicinal Chemistry Letters, Vol.14, No.18, pp. 4677-4684, ISSN 0960-894X

Li, N.N. (1978). Facilitated transport through liquid membranes. An extended abstract. Journal of Membrane Science, Vol.3. No.3, pp.265-279, ISSN 03767388

Lin, S.H. \& Chen, C.-N. (2006). Simultaneous reactive extraction separation of amino acids from water with D2EHPA in hollow fiber contactors. Journal of Membrane Science, Vol.280, No.1-2, pp. 771-780, ISSN 0376-7388

Lin, S.H.; Chen, C.N. \& Juang, R.S. (2006). Extraction equilibria and separation of phenylalanine and aspartic acid from water with di(2-ethylhexyl)phosphoric acid. Journal of Chemical Technology and Biotechnology. Vol.81, pp. 406-412, ISSN 0268-2575

Liu, Y.S. \& Dai, Y.Y. (2003). Distribution behavior of alpha-amino acids and aminobenzoic acid by extraction with trioctylamin. Separation Science and Technology, Vol.38, No.5, pp. 1217-1228, ISSN 0149-6395

Liu, Y.S.; Dai, Y.Y. \& Wang, H.D. (1999). Distribution behavior of 1-phenylalanine by extraction with di(2-ethylhexyl) phosphoric acid. Separation Science and Technology, Vol.34, pp. 2165-2176, ISSN 0149-6395

Luangrujiwong, P.; Sungpet, A.; Jiraratananon, R. \& Way, J. D. (2007). Investigation of the carrier saturation in facilitated transport of unsaturated hydrocarbons. Journal of Membrane Science, Vol.250, No.2, pp. 277-285, ISSN 0376-7388

Monteiro, T.I.R.C.; Porto, T.S.; Carneiro-Leão, A.M.A.; Silva, M.P.C. \& Carneiro-DaCunha, M.G. (2005). Reversed micellar extraction of an extracellular protease from Nocardiopsis sp. fermentation broth. Biochemical Engineering Journal, Vol.24, No.1, pp. 87-90, ISSN 1369-703X

Moo-Young, M.; Cooney, Ch.L. \& Humphrey, A.E. (1985). Comprehensive Biotechnology, Vol. 3, 254-270, Pergamon Press, ISBN 9780080262048, Oxford, UK

Naczk, M. \& Shahidi, F. (2004): Extraction and analysis of phenolics in food. Journal of Cromatography A, Vol.1054, No.1-2, pp. 95-102, ISSN 0021-9673

Noble, r.d. \& Stern, s.a. (1995). Membrane separations technology. Principles and applications, Elsevier, ISBN: 978-0-444-81633-7, London, UK

Palma, M.; Pineiro, Z. \& Barroso, C.J. (2002). In-line pressurized-fluid extraction-solidphase extraction for determining phenolic compounds in grapes. Journal of Cromatography A, Vol.968, No.1-2, pp. 1-5, ISSN 0021-9673

Parales, R.E.; Bruce, N.C.; Schmid, A. \& Wackett, L.P. (2002). Biodegradation, Biotransformation, and Biocatalysis (B3). Applied and Environmental Microbiology, Vol.68, No.10, pp. 4699-5005, ISSN 1098-5336

Park, S.S.; Park, J.H.; Kim, S.H. \& Hwang, S.H. (2003). Method for preparing paminobenzoic acid. Patent WO 072534/2003.

Rehm, H.J. \& Reed, G. (1993). Biotechnology, VCH, ISBN 3-527-25764.0, Weinheim, Deutschland 
Rosenkrantz, B.E.; Greco, J.R.; Hoogerheide, J.G. \& Oden, E.M. (1980). Gentamicin, In: Analytical profiles of drug substances, K. Florey (Ed.), Vol. 9, 295-340, Academic Press, ISBN: 0122608267, Orlando, USA

Saraf, A.S. \& Simonyan, A.V. (1992). Synthesis and antiallergic activity in a series of cinnamic acid. Pharmaceutical Chemistry Journal, Vol.26, No.7-8, pp. 598-605, ISSN 0091-150X

Savitskaya, E.M.; Yakhontova, L.F. \& Nys, P.S. (1982). Sorption of organic substances by ion exchangers of various nature. Pure Applied Chemistry, Vol.54, pp. 2169-2180, ISSN 1365-3075

Schuegerl, K. (1994). Solvent Extraction in Biotechnology, Springer, ISBN: 978-3-54057694-5, Berlin, Deutschland

Scovazzo, P.; Visser, A.E.; Davis Jr. J.H.; Rogers, R.D.; Koval, C.A.; DuBois, D.L. \& Noble, R.D. (2002). Supported ionic liquid membranes and facilitated ionic liquid membranes, In: Ionic liquids: industrial applications to green chemistry, Rogers, R.D., Seddon, K.R., (Ed.), 69-87, ACS Symposium Series 818, ISBN 978-0841237896, Washington, USA

Silverman, R.B. (2004). The organic chemistry of drug design and drug action, Second edition, Elsevier Academic Press, ISBN 978-0-12-643732-4, London, UK

Smelz, E.A.; Engelberth, J.; Tumlinson, J.H.; Block, A. \& Alborn, H.T. (2004). The use of vapor phase extraction in metabolic profiling of phytohormones and other metabolites. The Plant Journal, Vol.39, No.5, pp. 790-796, ISSN 1365-313X

Tan, B.; Luo, G. \& Wang, J. (2007). Extractive separation of amino acid enantiomers with co-extractants of tartaric acid derivative and aliquat-336. Separation and Purification Technology, Vol.53, No.3, pp. 330-336, ISSN 13835866

Tawata, S.; Taira, S.; Kobamoto, N.; Zhu, J.; Ishihara, M. \& Toyama, S. (1996). Synthesis and antifungal activity of cinnamic acid esters. Bioscience, Biotechnology and Biochemistry, Vol. 60, No.5, pp. 909-1004, ISSN 1347-6947

Teramoto, M.; Matsuyama, H. \& Yonehara, T. (1990). Selective facilitated transport of benzene across supported and flowing liquid membranes containing silver nitrate as a carrier. Journal of Membrane Science, Vol.50, No.3, pp. 269-277, ISSN 0376-7388

Vijayakumar, J.; Aravindan, R. \& Viruthagiric, T. (2008). Recent Trends in the Production, Purification and Application of Lactic Acid. Chemical and Biochemical Engineering Quarterly, Vol.22, No.2, pp. 245-264, ISSN 0352-9568

Weast, R.C. (1974). Handbook of Chemistry and Physics, 54th edition, CRC Press, ISBN: 0849304814, Cleveland, USA

Williams, D.A. \& Lemke, T.L. (2002). Foye's Principles of Medicinal Chemistry, Fifth edition, Lippincot Williams \& Wilkins, ISBN 978-0-7817-6879-5, New York, USA

Yordanov, B. \& Boyadzhiev, L. (2004). Pertraction of citric acid by means of emulsion liquid membranes. Journal of Membrane Science, Vol.238, No.2, pp. 191-198; ISSN 0376-7388 
Yoshizawa, S.; Fourmy, D. \& Puglishi, J.D. (1998). Structural origin of gentamicin antibiotic action. The EMBO Journal, Vol.17, pp. 6437-6448, ISSN 0261-4189 


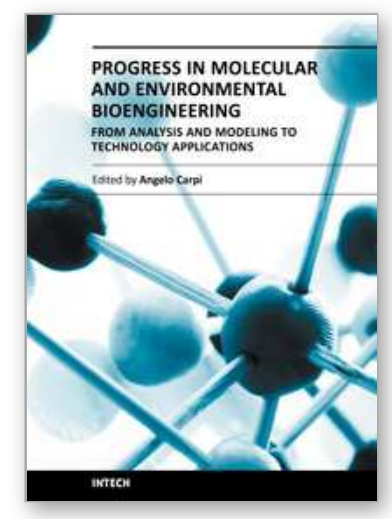

\author{
Progress in Molecular and Environmental Bioengineering - From \\ Analysis and Modeling to Technology Applications \\ Edited by Prof. Angelo Carpi
}

ISBN 978-953-307-268-5

Hard cover, 646 pages

Publisher InTech

Published online 01, August, 2011

Published in print edition August, 2011

This book provides an example of the successful and rapid expansion of bioengineering within the world of the science. It includes a core of studies on bioengineering technology applications so important that their progress is expected to improve both human health and ecosystem. These studies provide an important update on technology and achievements in molecular and cellular engineering as well as in the relatively new field of environmental bioengineering. The book will hopefully attract the interest of not only the bioengineers, researchers or professionals, but also of everyone who appreciates life and environmental sciences.

\title{
How to reference
}

In order to correctly reference this scholarly work, feel free to copy and paste the following:

Anca-Irina Galaction and Dan Caşcaval (2011). Separation of Biosynthetic Products by Pertraction, Progress in Molecular and Environmental Bioengineering - From Analysis and Modeling to Technology Applications, Prof. Angelo Carpi (Ed.), ISBN: 978-953-307-268-5, InTech, Available from:

http://www.intechopen.com/books/progress-in-molecular-and-environmental-bioengineering-from-analysisand-modeling-to-technology-applications/separation-of-biosynthetic-products-by-pertraction

\section{INTECH}

open science | open minds

\section{InTech Europe}

University Campus STeP Ri

Slavka Krautzeka 83/A

51000 Rijeka, Croatia

Phone: +385 (51) 770447

Fax: +385 (51) 686166

www.intechopen.com

\section{InTech China}

Unit 405, Office Block, Hotel Equatorial Shanghai

No.65, Yan An Road (West), Shanghai, 200040, China

中国上海市延安西路65号上海国际贵都大饭店办公楼 405 单元

Phone: +86-21-62489820

Fax: $+86-21-62489821$ 
(C) 2011 The Author(s). Licensee IntechOpen. This chapter is distributed under the terms of the Creative Commons Attribution-NonCommercialShareAlike-3.0 License, which permits use, distribution and reproduction for non-commercial purposes, provided the original is properly cited and derivative works building on this content are distributed under the same license. 